$$
\text { DOE/PC } 89651-T_{3}
$$

$\mathrm{DOE} / \mathrm{PC} / 89651--\mathrm{T} 3$

INNOVATIVE CLEAN COAL TECHNOLOGY (ICCT) DE92 010964

\author{
500 MW DEMONSTRATION OF ADVANCED \\ WALL-FIRED COMBUSTION TECHNIQUES \\ FOR THE REDUCTION OF NITROGEN OXIDE (NOx) \\ EMISSIONS FROM COAL-FIRED BOILERS
}

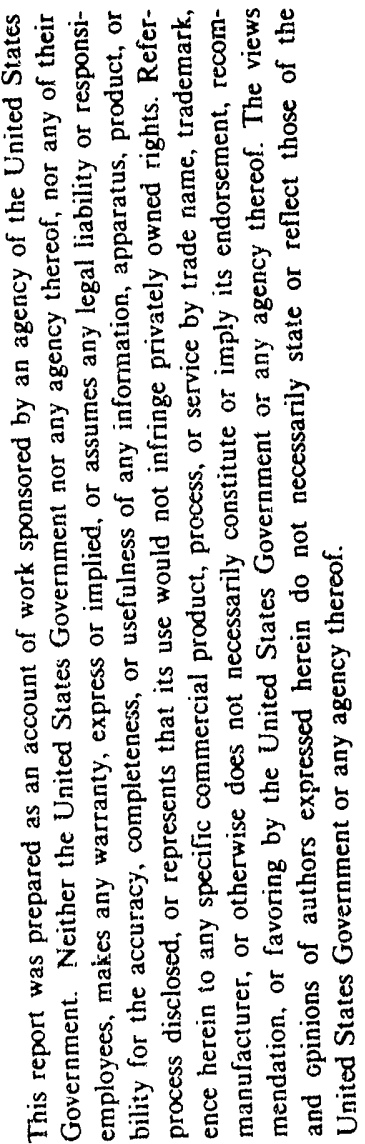

Technical Progress Report

Third Quarter 1991

DOE Contract Number

DE-FC22-90PC89651

SCS Contract Number

C-91-000027

Prepared by:

Southern Company Services, Inc.

800 Shades Creek Parkway

Birmingham, Alabama 35209 ;

Cleared by DOE Patent Council on November 18, 1991 


\section{LEGAL NOTICE}

This report was prepared by Southern Company Services, Inc. pursuant to a cooperative agreement partially funded by the U.S. Department of Energy and neither Southern Company Services, Inc. nor any of its subcontractors nor the U.S. Department of Energy, nor any person acting on behalf of either:

(a) Makes any warranty or representation, express or implied with respect to the accuracy, completeness, or usefulness of the information contained in this report, or process disclosed in this report may not infringe privately-owned rights; or

(b) Assumes any liabilities with respect to the use of, or for damages resulting from the use of, any information, apparatus, method or process disclosed in this report.

Reference herein to any specific commercial product, process, or service by trade name, trademark, manufacturer, or otherwise, does not necessarily constitute or imply its endorsement, recommendation, or favoring by the U.S. Department of Energy. The views and opinion of authors expressed herein do not necessarily state or reflect those of the U.S. Department of Energy. 


\section{EXECUTIVE SUMMARY}

This quarterly report discusses the technical progress of an Innovative Clean Coal Technology (ICCT) demonstration of advanced wall-fired combustion techniques for the reduction of nitrogen oxide $\left(\mathrm{NO}_{\mathrm{X}}\right)$ emissions from coal-fired boilers. The project is being conducted at Georgia Power Company's Plant Hammond Unit 4 located near Rome, Georgia. The primary goal of this project is the characterization of the low $\mathrm{NO}_{\mathrm{X}}$ combustion equipment through the collection and analysis of long-term emissions data. A target of achieving fifty percent $\mathrm{NO}_{\mathbf{X}}$ reduction using combustion modificricions has been established for the project.

The project provides a stepwise retrofit of an Advanced Overfire Air (AOFA) system followed by Low $\mathrm{NO}_{\mathrm{X}}$ Burners (LNB). During each test phase of the project, diagnostic, performance, long-term, and verification testing will be performed. These tests are used to quantify the $\mathrm{NO}_{\mathrm{X}}$ reductions of each technology and evaluate the effects of those reductions on other combustion parameters such as particulate characteristics and boiler efficiency.

Phase 3 LNB testing began in July 1991. Short-term tests indicated post-retrofit, full-load $\mathrm{NO}_{\mathbf{x}}$ levels of approximately $0.65 \mathrm{lb} / \mathrm{MBtu}$ and flyash loss-on-igniticn values of 8 percent. For comparison, the baseline values were approximately $1.35 \mathrm{lb} / \mathrm{MBtu}$ at 5.2 percent LOI. Long-term testing of the LNBs is now in progress. As of September 30, 1991, thirty-seven (37) days of long-term data had been collected. Preliminary analysis of the long-term data through September 14, 1991 indicates full-load $\mathrm{NO}_{\mathrm{X}}$ emission levels of approximately .65 lb/MBtu. This NOx emission level could change considerably when the complete long-term data set is analyzed. Tests performed in August indicate higher precipitator particulate loading and flue gas flow rates for LNB operation as compared to baseline operation. A research effort is being organized within the Southern Company to investigate and mitigate the adverse effects of low $\mathrm{NO}_{\mathrm{x}}$ burners on precipitator performance. While the particulate emissions issues are being resolved, long-term data collection at reduced loads will continue. 


\section{TABLE OF CONTENTS}

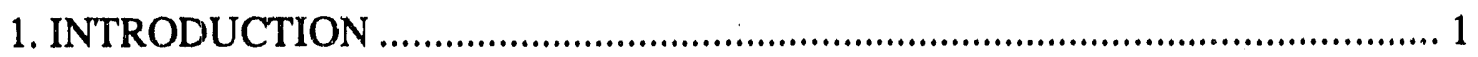

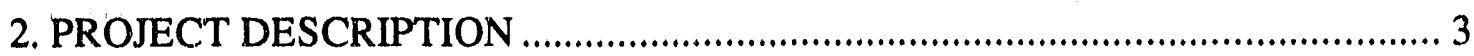

2.1. Test Program Methodology .................................................................... 3

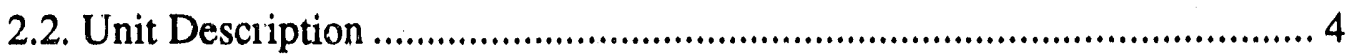

2.3. Advanced Overfire Air (AOFA) System............................................. 5

2.4. Wall-Fired Low NOx Combustion System................................................... 6

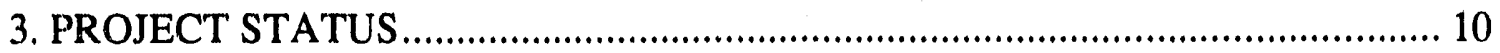

3.1. Phase 1 - Baseline Characterization ........................................................ 10

3.1.1. Task 1.5 Baseline Testing...................................................... 10

3.2. Phase 2 - Advanced Overfire Air Retrofit ................................................ 10

3.2.2. Task 2.3 AOFA Testing ........................................................ 10

3.3. Phase 3 - Low NOx Burner Retrofit........................................................ 11

3.3.1. Task 3.2 LNB Design and Retrofit ............................................ 11

3.3.1.1. LNB Installation Outage ............................................ 11

3.3.1.2. LNB Optimization ....................................................... 11

3.3.2. Task 3.3 LNB Testing with and Without AOFA.......................... 11

3.3.3. ECEM Certification ........................................................... 13

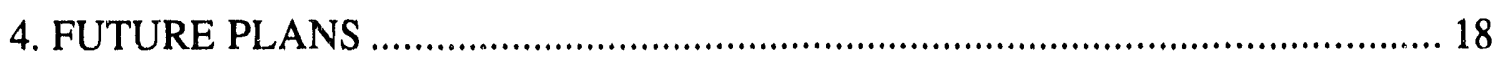

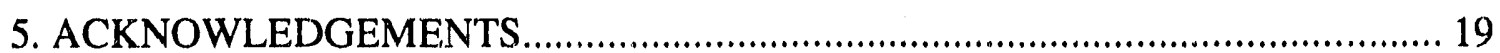

APPENDIX A - Phase 3 Long-Term $\mathrm{NO}_{\mathrm{x}}$ Emissions and Generation

APPENDIX B - Phase 3 CEM Certification Report 


\section{INTRODUCTION}

This document discusses the technical progress of a U. S. Department of Energy (DOE) Innovative Clean Coal Technology (ICCT) Project demonstrating advanced wall-fired combustion techniques for the reduction of nitrogen oxide $\left(\mathrm{NO}_{\mathrm{x}}\right)$ emissions from coalfired boilers. The project is being conducted at Georgia Power Company's Plant Hammond Unit 4 (500 MWe) near Rome, Georgia.

The project is being managed by Southern Company Services, Inc. (SCS) on behalf of the project co-funders: The Southern electric system, the U. S. Department of Energy (DOE), and the Electric Power Research Institute. In addition to SCS, The Southern electric system includes five electric operating companies: Alabama Power, Georgia Power, Gulf Power, Mississippi Power, and Savannah Electric and Power. SCS provides engineering, research, and financial services to the Southern electric system.

The Clean Coal Technology Program is a jointly funded effort between government and industry to move the most promising advanced coal-based technologies from the research and development stage to the commercial marketplace. The Clean Coal effort sponsors projects which are different from traditional research and development programs sponsored by the DOE. Traditional projects focus on long range, high risk, high payoff technologies with the DOE providing the majority of the funding. In contrast, the goal of the Clean Coal Projects is to demonstrate commercially feasible, advanced coal-based technologies which have already reached the "proof of concept" stage. As a result, the Clean Coal Projects are jointly funded endeavors between the government and the private sector which are conducted as Cooperative Agreements in which the industrial participant contributes at least fifty percent of the total project cost.

The primary objective of the Plant Hammond demonstration is to determine the long-term effects of commercially available wall-fired low $\mathrm{NO}_{\mathrm{x}}$ combustion technologies on $\mathrm{NO}_{\mathrm{x}}$ emissions and boiler performance. Short-term tests of each technology are also being performed to provide engineering information about emissions and performance trends. A target of achieving fifty percent $\mathrm{NO}_{\mathrm{x}}$ reduction using combustion modifications has been established for the project. Specifically, the objectives of the projects are: 
1. Demonstrate in a logical stepwise fashion the short-term $\mathrm{NO}_{\mathrm{x}}$ reduction capabilities of the following advanced low $\mathrm{NO}_{\mathrm{X}}$ combustion technologies:
a. Advanced Overfire Air (AOFA)
b. Low $\mathrm{NO}_{\mathrm{X}}$ Burners (LNB)
c. LNB with AOFA

2. Determine the dynarnic, long-term emissions characteristics of each of these combustion $\mathrm{NO}_{\mathrm{x}}$ reduction methods using sophisticated statistical techniques.

3. Evaluate the progressive cost effectiveness (i.e., dollars per ton $\mathrm{NO}_{\mathbf{x}}$ removed) of the low $\mathrm{NO}_{\mathrm{x}}$ combustion techniques tested.

4. Determine the effects on other combustion parameters (e.g., CO production, carbon carryover, particulate characteristics) of applying the $\mathrm{NO}_{\mathrm{x}}$ reduction methods listed above. 


\section{PROJECT DESCRIPTION}

\subsection{Test Program Methodology}

In order to accomplish the project objectives, a Statement of Work (SOW) was developed which included the Work Breakdown Structure (WBS) found in Table 1. The WBS is designed around a chronological flow of the project. The chronology requires design, construction, and operation activities in each of the first three phases following project award.

The stepwise approach to evaluating the $\mathrm{NO}_{\mathrm{x}}$ control technologies requires that three plant outages be used to successively install (1) the test instrumentation, (2) the AOFA system, and (3) the LNBs. These outages were scheduled to coincide with existing plant maintenance outages in the fall of 1989, spring of 1990, and the spring of 1991. The planned retrofit progression has allowed for an evaluation of the AOFA system while operating with the existing pre-retrofit burners. As shown in Figures 1 and 2, the AOFA air supply is separately ducted from the existing forced draft secondary air system. Backpressure dampers are provided on the secondary air ducts to allow for the introduction of greater quantities of higher pressure overfire air into the boiler. The burners are designed to be plug-in replacements for the existing circular burners.

The Data Acquisition System (DAS) for the Hammond Unit 4 ICC' $T$ project is a custom designed microcomputer based system used to collect, format, calculate, store, and transmit data derived from power plant mechanical, thermal, and fluid processes. The extensive process data selected for input to the DAS has in common a relationship with either boiler performance or boiler exhaust gas properties. This system includes a continuous emissions monitoring system $\left(\mathrm{NO}_{\mathrm{x}}, \mathrm{SO}_{2}, \mathrm{O}_{2}, \mathrm{THC}, \mathrm{CO}\right)$ with a multi-point flue gas sampling and conditioning system, an acoustic pyrometry and thermal mapping system, furnace tube heat flux transducers, and boiler efficiency instrumentation. The instrumentation system is designed to provide data collection flexibility to meet the schedule and needs of the various testing efforts throughout the demonstration program. A summary of the type of data cc!lected is shown in Table 2.

Following each outage, a series of four groups of tests are planned. These are (1) diagnostic, (2) performance, (3) long-term, and (4) verification. The diagnostic, 
performance, and verification tests consist of short-term data collection during carefully established operating conditions. The diagnostic tests are designed to map the effects of changes in boiler operation on $\mathrm{NO}_{\mathrm{x}}$ emissions. The performance tests evaluate a more comprehensive set of boiler and combustion performance indicators. The results from these tests will include particulate characteristics, boiler efficiency, and boiler outlet emissions. Mill performance and air flow distribution are also tested. The verification tests are performed following the end of the long-term testing period and serve to identify any potential changes in plant operating conditions.

As stated previously, the primary objective of the demonstration is to collect long-term, statistically significant quantities of data under normal operating conditions with and without the various $\mathrm{NO}_{\mathrm{x}}$ reduction technologies. Earlier demonstrations of emissions control technologies have relied solely on data from a matrix of carefully established short-term (one to four hour) tests. However, boilers are not typically operated in this manner, considering plant equipment inconsistencies and economic dispatch strategies. Therefore, statistical analysis methods for long-term data are available that can be used to determine the achievable emissions limit or projected emission tonnage of an emissions control technology. These analysis methods have been developed over the past fifteen years by the Control Technology Cornmittee of the Utility Air Regulatory Group (UARG). Recause the uncertainty in the analysis methods is reduced with increasing data set size, UARG recominends that acceptable results can be achieved with data sets of at least 51 days with each day containing at least 18 valid hourly averages.

\subsection{Unit Description}

Georgia Power Company's Plant Hammond Unit 4 is a Foster Wheeler Energy Corporation (FWEC) balanced draft, opposed wall-fired boiler rated at 500 gross MWe with design steam conditions of $2500 \mathrm{psig}$ and 1000/1000 of superheat/reheat temperatures, respectively. Prior to the LNB retrofit, six FWEC Planetary Roller and Table type mills provided pulverized eastern bituminous coal $(12,900 \mathrm{Btu} / \mathrm{lb}, 33 \% \mathrm{VM}$, $53 \% \mathrm{FC}, 1.7 \% \mathrm{~S}, 1.4 \% \mathrm{~N}$ ) to 24 Intervane burners. During the recent LNB outage, the existing burners were replaced with FWEC Control Flow/Split Flame burners and in addition, two of the existing mills were replaced with Babcock and Wilcox MPS 75 mills. The burners are arranged in a matrix of 12 burners $(4 \mathrm{~W} \times 3 \mathrm{H})$ on opposing walls with each mill supplying coal to 4 burners in an elevation. As part of this demonstration 
project, the unit was retrofitted with an Advanced Overfire Air System (AOFA), to be described later. The unit is equipped with a coldside ESP and utilizes two Ljungstrom air preheaters. Plant Hammond is located near Rome, Georgia, northwest of Atlanta.

Table 1: Work Breakdown Structure

500 MW Demonstration of Advanc?d Wall-Fired Combustion Techniques for the Reduction of Nitrogen Oxide (NOx) Emissions from Coal-Fired Boilers

\begin{tabular}{|c|l|l|c|}
\hline Phase & \multicolumn{1}{|c|}{ Task } & \multicolumn{1}{|c|}{ Description } & Date \\
\hline 0 & 1.0 & Phase 0 Pre-Award Negotiations & \\
& & & \\
& 1.1 & Phase 1 Baseline Characterization & \\
& 1.1 .1 & Project Management and Reporting & $8 / 89-4 / 90$ \\
& 1.1 .2 & Site Preparation & $8 / 89-10 / 89$ \\
& 1.1 .3 & Flow Modeling & $9 / 89-6 / 90$ \\
& 1.1 .4 & Instrumentation & $9 / 89-10 / 89$ \\
& 1.1 .5 & Baseline Testing & $11 / 89-4 / 90$ \\
2 & 1.2 & Phase 2 Advanced Overfire Air Retrofit & \\
& 1.2 .1 & Project Management and Reporting & $4 / 90-3 / 91$ \\
& 1.2 .2 & AOFA Design and Retrofit & $4 / 90-5 / 90$ \\
& 1.2 .3 & AOFA Testing & $5 / 90-3 / 91$ \\
3 & 1.3 & & \\
& 1.3 .1 & Phase 3 Low NOx Burner Retrofit & $3 / 91-4 / 92$ \\
& 1.3 .2 & Project Management and Reporting & $3 / 91-5 / 91$ \\
& 1.3 .3 & LNB Design and Retrofit & $5 / 91-4 / 92$ \\
4 & 1.4 & Final Reporting and Disposition & \\
& 1.4 .1 & Project Management and Reporting & $4 / 92-12 / 5.2$ \\
& 1.4 .2 & Disposition of Hardware & $5 / 92$ \\
\hline
\end{tabular}

\subsection{Advanced Overfire Air (AOFA) System}

Generally, combustion $\mathrm{NO}_{\mathrm{x}}$ reduction techniques attempt to stage the introduction of oxygen into the furnace. This staging reduces $\mathrm{NO}_{\mathrm{x}}$ production by creating a delay in fuel and air mixing which lowers combustion temperatures. This staging also reduces the quantity of oxygen available to the fuel-bound nitrogen. Typical overfire air (OFA) systems accomplish this staging by diverting ten to twenty percent of the total combustion air to ports located above the primary combustion zone. AOFA improves this concept by introducing the OFA through separate ductwork in greater quantities, 
with more control, and at higher pressures (Figure 2). The resulting system is capable of providing deep staging of the combustion process with accurate measurement of the AOFA airflow.

\subsection{Wall-Fired Low NOx Combustion Systern}

Low $\mathrm{NO}_{\mathrm{x}}$ burner systems attempt to stage the combustion without the need for the additional ductwork and furnace ports required by OFA and AOFA systems. These commercially-available burner systems introduce the air and coal into the furnace in a well controlled, reduced turbulence manner. To achieve this, the burner must regulate the initial fuel/air mixture, velocities and turbulence to create a fuel-rich core, with sufficient air to sustain combustion at a severely sub-stoichiometric air/fuel ratio. The burner must then control the rate at which additional air, necessary to complete combustion, is mixed with the flame solids and gases to maintain a deficiency of oxygen until the remaining combustibles fall below the peak $\mathrm{NO}_{\mathrm{x}}$ producing temperature (around $2800^{\circ} \mathrm{F}$ ). The final excess air can then be allowed to mix with the unburned products so that the combustion is completed at lower temperatures. Burners have been developed for single wall and opposed wall boilers.

Foster Wheeler Energy Corporation (FWEC) was competitively selected to design, fabricate, and erect the opposed wall, low $\mathrm{NO}_{\mathrm{x}}$ burner shown in Figure 3 and the AOFA system described above. In the FWEC Controlled Flow/Split Flame (CFSF) burner, secondary combustion air is divided between inner and outer flow cylinders. A sliding sleeve damper regulates the total secordary air flow entering the burner and is used to balance the burner air flow distribution. An adjustable outer register assembly divides the burners secondary air into two concentric paths and also imparts some swirl to the air streams. The secondary air which traverses the inner path, flows across an adjustable inner register assembly that, by providing a variable pressure drop, apportions the flow between the inner and outer flow paths. The inner register also controls the degree of additional swirl imparted to the coal/air mixture in the near throat region. The outer air flow enters the furnace axially, providing the remaining air necessary to complete combustion. An axially movable inner sleeve tip provides a means for varying the primary air velocity while maintaining a constant primary flow. The split flame nozzle segregates the coal/air mixture into four concentrated streams, each of which forms an individual flame when entering the furnace. This segregation minimizes mixing between the coal and the primary air, assisting in the staged combustion process. The adjustments 
to the sleeve dampers, inner registers, outer registers, and tip position are made during the burner optimization process and thereafter remain fixed unless changes in plant operation or equipment condition dictate further adjustments. 


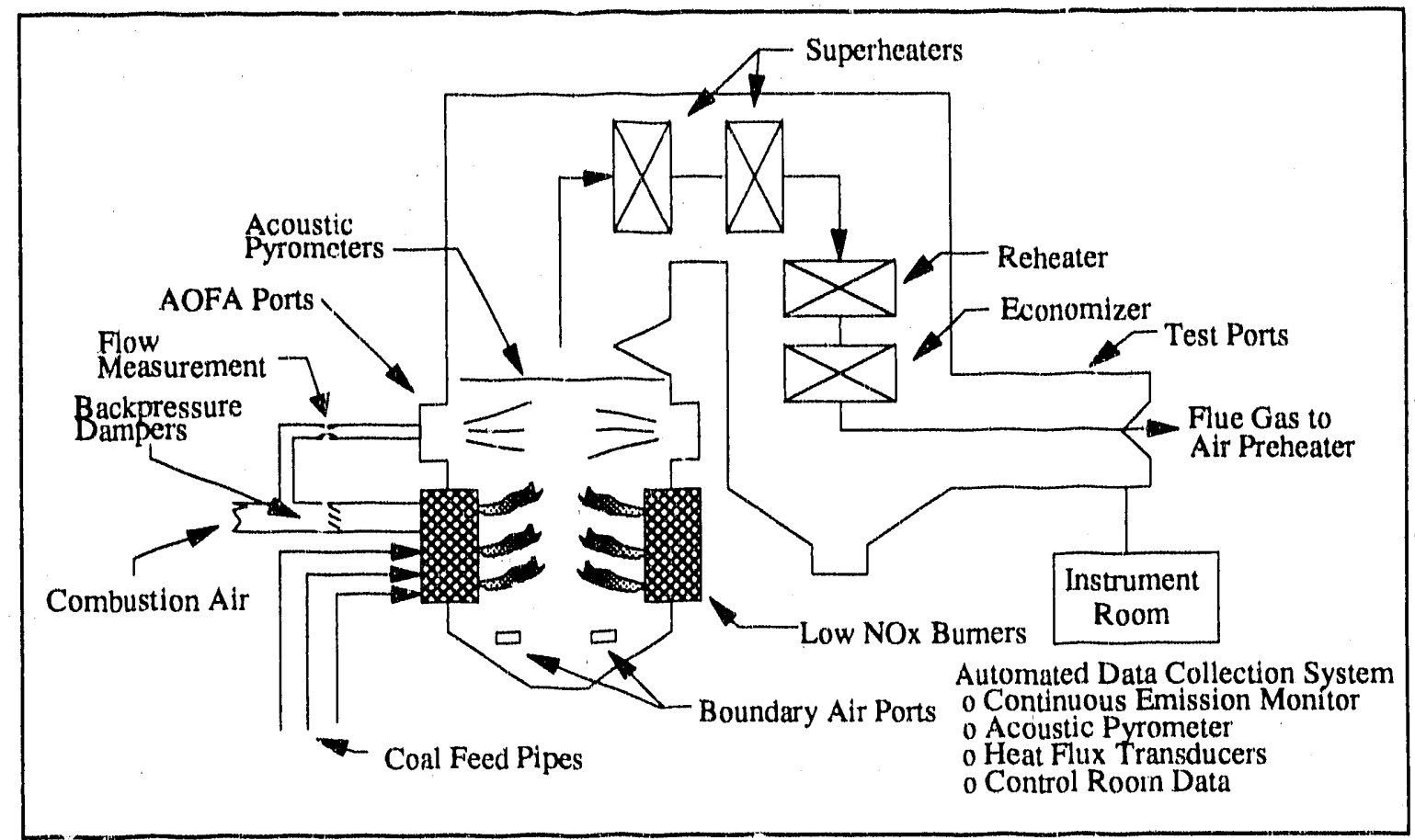

Figure 1: Plant Hammond Unit 4 Boiler

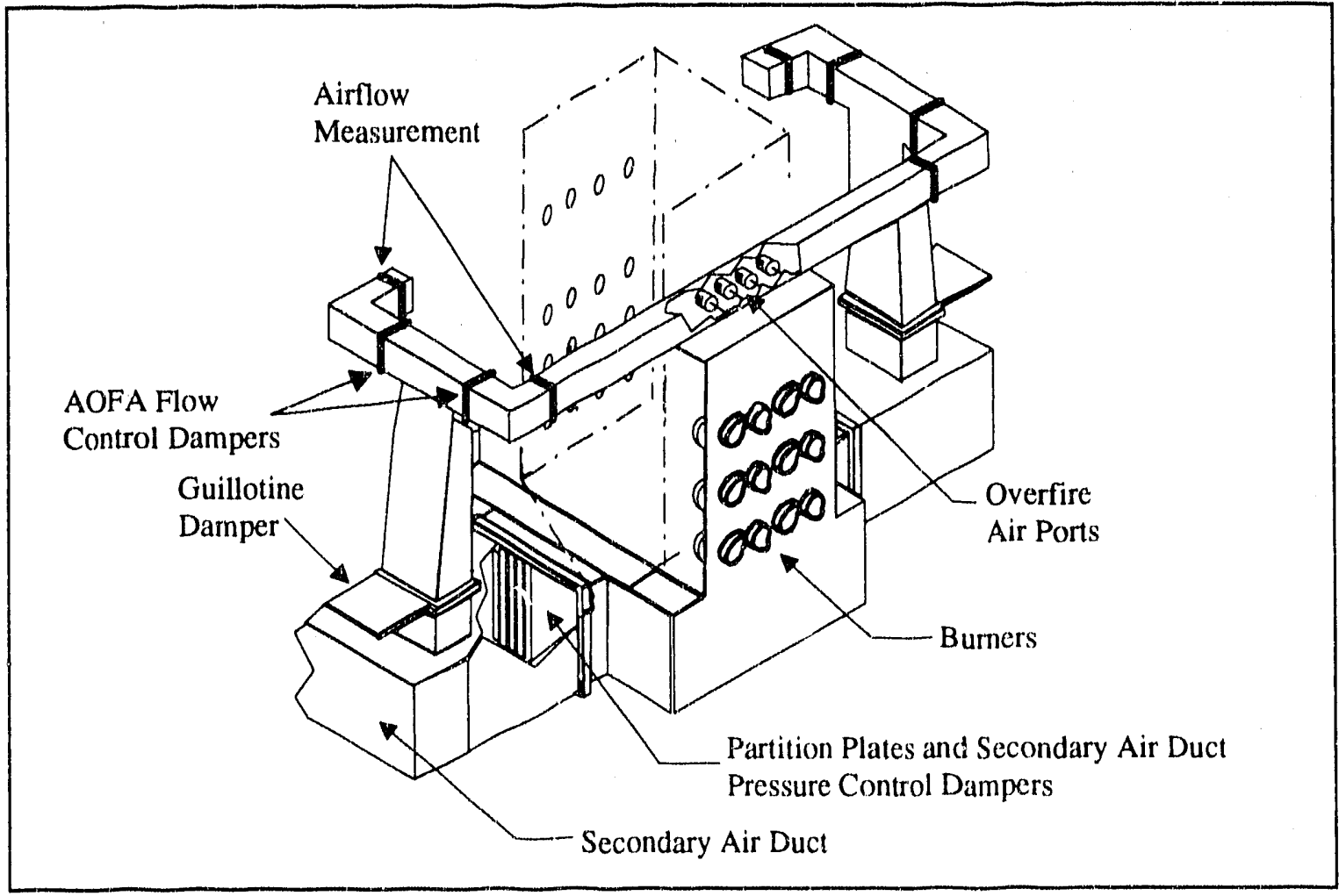

Figure 2: $\quad$ Advanced Overfire Air System 


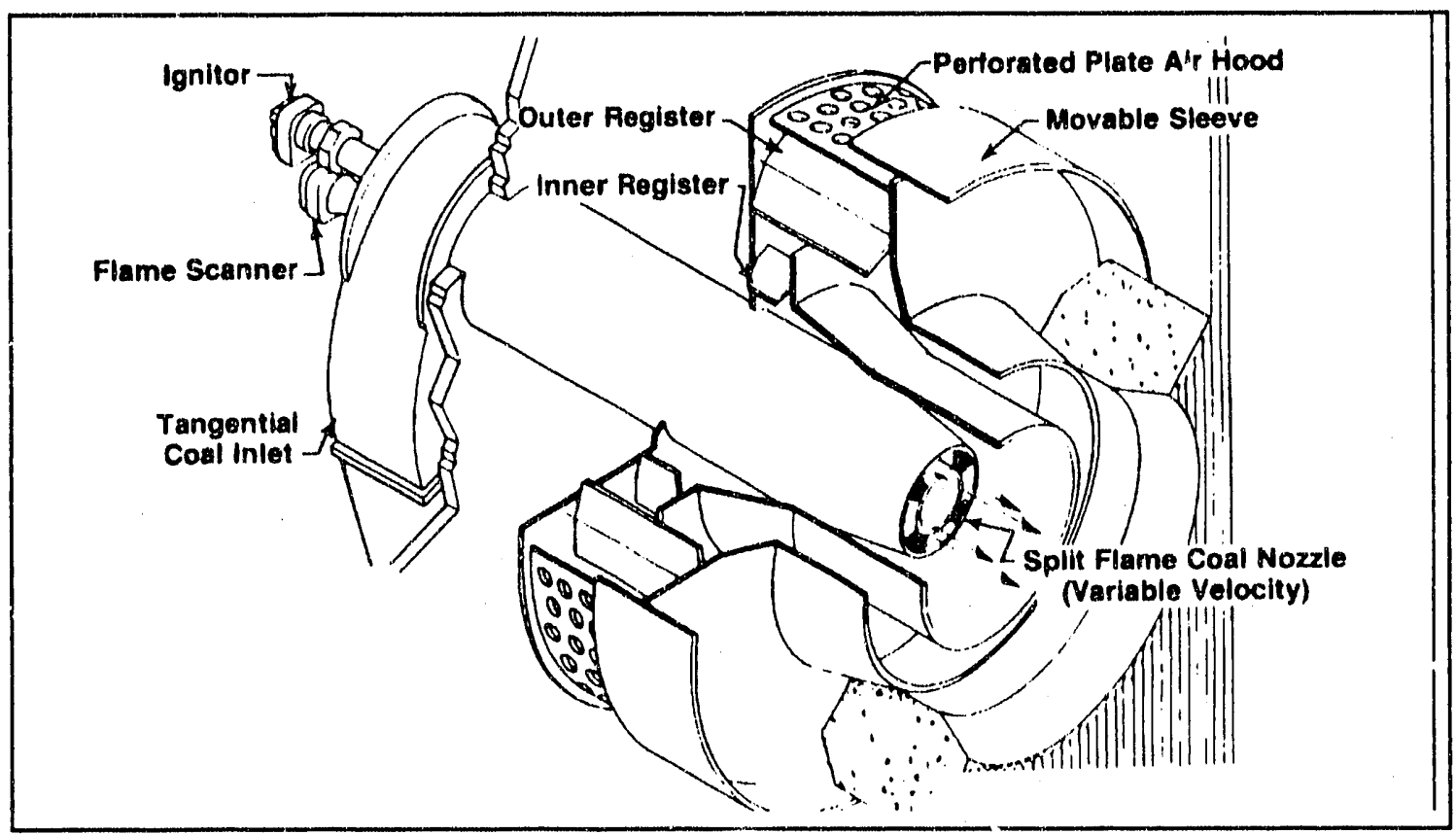

Figure 3: Lov' $\mathrm{NO}_{\mathrm{x}}$ Burner Installed at Plant Hammond

Table 2: Plant Data Pcints

\begin{tabular}{|c|c|}
\hline Boiler Drum Pressure & Superheat Outiet Pressure \\
\hline Cold Reheat Pressure & Hot Rehcat Pressure \\
\hline Barometric Pressure & Superheat Spray Flow \\
\hline Reheat Spray Flow & Main Steam Flow \\
\hline Feedwater Flow & Coal Flows \\
\hline Secondary Air Flows & Primary Air Flows \\
\hline Main Steam Temperature & Cold Reheat Temperature \\
\hline Hot Reheat Temperature & Feedwater Temperature \\
\hline Desuperheater Outlet Temp. & Desuperheater Inlet Temp. \\
\hline Economizer Outlet Temp. & Air Heater Air Inlet Temp. \\
\hline Air Heater Air Outlet Temp. & Ambient Temperature \\
\hline BFP Discharge Temperature & Relative Humidity \\
\hline Stack NOx & Stack SO2 \\
\hline Stack O2 & Stack Opacity \\
\hline Generation & Overfire Air Flows \\
\hline
\end{tabular}




\section{PROJECT STATUS}

\subsection{Phase 1 - Baseline Characterization}

\subsubsection{Task 1.5 Baseline Testing}

Phase 1 baseline testing ended in April 1990. A sunmary of $\mathrm{NO}_{\mathrm{x}}$ emissions from Phase 1 short- and long-term testing is presented in Figure 4. The long-term data demonstrates a full-load, mean $\mathrm{NO}_{\mathrm{x}}$ level of $1.24 \mathrm{lb} / \mathrm{MBtu}$ at the nominal 2.7 percent excess oxygen operating condition while the short-term test results show a mean level of $1.35 \mathrm{lb} / \mathrm{MBtu}$ ( 9 percent difference). The explanation for this disparity most likely is a result of such variables as coal variability, minor unit operating changes (air register settings, etc.) and possibly weather conditions affecting the coal grinding (wet coal) as well as the fact that long-term data includes transients in operating $\mathrm{O}_{2}$ level which may be greater than the steady load excursions. The important point is that these normal excursions can influence the short-term data taken at one point in time but are essentially averaged out during normal, long-term operation.

\subsection{Phase 2 - Advanced Overfire Air Retrofit}

\subsubsection{Task 2.3 AOFA Testing}

Phase 2 AOFA testing ended in March 1991. A summary of $\mathrm{NO}_{\mathrm{x}}$ emissions from Phase 1 short- and long-term testing is presented in Figure 4. The short-term tests results from the AOFA operation show a substantial reduction (up to 40 percent at full-load reducing to 25 percent at $300 \mathrm{MW}$ ) in $\mathrm{NO}_{\mathrm{x}}$ emissions. However, long-term tests indicate a maximum $\mathrm{NO}_{\mathrm{x}}$ emissions reduction of only 25 percent. The difference between the short- and long-term test results emanate from the same operating variabilities as discussed previously and a change in operating excess air $\mathrm{O}_{2}$ levels between these two test segments. 


\subsection{Phase 3 - Low $\mathrm{NO}_{\mathrm{x}}$ Burner Retrofit}

\subsubsection{Task 3.2 LNB Design and Retrofit}

\subsubsection{LNB Installation Outage}

The new LNBs were installed during a seven week outage starting March 8, 1991, and continuing to April 28, 1991. Prior to the outage, rigging was installed, access pathways were formed, and when possible, insulation and lagging were removed. Although no pressure part modifications were required, installation of the new FWEC burners was far from simple. Complicating factors included craft labor shortages, the presence of asbestos and unacceptable levels of arsenic in the boiler, and the requirement to coordinate with the many other work activities occurring at the plant during a major outage. Approximately thirty craft personnel were involved in the retrofit, working a single, ten-hour shift, six days a week for four weeks and two, ten-hour shifts, six days a week for the remaining three weeks. This outage is described in more detail in the Second Quarter 1991 Technical Progress Report.

\subsubsection{LNB Optimization}

Optimization of the burners for $\mathrm{NO}_{\mathrm{x}}$ reduction was performed by FWEC personnel during a three week period in June. The optimization required that the unit be taken out of economic dispatch and run at full-load for much of the optim zation period. After balancing the secondary air flows, the burner optimization process was accomplished by adjusting the inner registers, outer registers, slide nozzles, and sleeve dampers while monitoring $\mathrm{NO}_{\mathrm{x}}, \mathrm{O}_{2}$, and $\mathrm{CO}$ at the economizer outlet using the ECEM and DAS. When possible, burner adjustments of the same class (the classes being inner register, outer register, slide nozzle, and sleeve damper) were moved in unison to a nominal, optimized position. Only when flow and/or combustion irregularities dictated, were individual dampers adjusted from this nominal position. Further information on the optimization proces: can be found in the Second Quarter 1991 Technical Progress Report.

\subsubsection{Task 3.3 LNB Testing with and Without AOFA}

Phase 3A diagnostic testing of the low $\mathrm{NO}_{\mathrm{x}}$ burner system began on July 9, 1991 and was completed on July 15 . Performance testing began July 16 . This testing indicated that the low $\mathrm{NO}_{\mathrm{x}}$ burners were not optimally configured and therefore testing was 
postponed for four days to allow FWEC personnel to make additional adjustments to the new burners and ancillary systems. Testing continued on July 22 and was completed July 28. A summary of the tests are shown in Table 3. Preliminary findings from these tests indicate short-term, full-load $\mathrm{NO}_{\mathrm{x}}$ emissions of approximately .65 lb/MBtu at flyash loss-on-ignition (LOI) values of 8 percent (Figures 4 and 5). For comparison, the baseline values were approximately $1.35 \mathrm{lb} / \mathrm{MBtu}$ at 5.2 percent LOI. Further short-term testing is planned during this test phase in which additional adjustments to the burners will be made to determine if $\mathrm{LOI}$ can be reduced without adversely impacting $\mathrm{NO}_{\mathrm{x}}$ production.

Long-term testing of the low $\mathrm{NO}_{\mathrm{x}}$ burners began on August 7, 1991. As of September 30, 1991, thirty-seven (37) days of long-term data have been collected. Preliminary analysis of the long-term data through September 14, 1991 indicates full-load $\mathrm{NO}_{\mathrm{X}}$ emission levels of approximately .65 lb/MBtu (Figure 4). Since approximately thirty (30) days remain in this long-term test period, the $\mathrm{NO}_{\mathrm{x}}$ emission level could change considerably when the complete long-term data set is analyzed. As in the baseline long-term test period, $\mathrm{NO}_{\mathrm{X}}$ emissions generally increased with load, however below approximately $275 \mathrm{MW}$, the converse is true and $\mathrm{NO}_{\mathrm{X}}$ emissions rapidly increase with decreasing load. $\mathrm{NO}_{\mathrm{X}}$ emissions during the AOFA long-term test phase were not highly dependent on load as in the other two phases. Appendix A shows the $\mathrm{NO}_{\mathrm{X}}$ emissions and unit generation trends for each week of the of the long-term test phase. This data was recorded in five minute intervals using the data acquisition system at the site. For reasons discussed below, after September 6, 1991, maximum load for the unit has been limited to $300 \mathrm{MW}$.

As shown in Figure 6, baseline $\mathrm{CO}$ emissions were highly dependent on load, increasing from approximately $10 \mathrm{ppm}$ at minimum load to $100 \mathrm{ppm}$ at full load. This dependency was not evident in either the long-term AOFA testing or the short-term LNB tests, for which maximum $\mathrm{CO}$ values were approximately $20 \mathrm{ppm}$. This change is probably attributable to plant operating personnel beginning to monitor $\mathrm{CO}$ emission levels and taking action to reduce these emissions. Prior to the AOFA long-term test phase, $\mathrm{CO}$ emission levels were not displayed in the control room.

Full-load, long-term stack $\mathrm{O}_{2}$ levels for the LNB test phase were approximately thirty-four (34) percent higher than the corresponding baseline values (Figure 7). This change in $\mathrm{O}_{2}$ level is mostly attributable to an increase of approximately six (6) percent 
in combustion air for the LNB test configuration. Although an increase in the stack $\mathrm{O}_{2}$ is indicated in this figure, the combustion air to the furnace did not change appreciably between the baseline and AOFA test phases, the change in $\mathrm{O}_{2}$ levels primary cause being leakage in the furnace backpass.

Results from this project indicate that operation with low $\mathrm{NO}_{\mathrm{x}}$ burners has substantially reduced boiler slagging. The site has also noticed a reduction in bottom ash production. However, the particulate that had previously been deposited on the boiler waterwalls and in the bottom hoppers is now exiting the furnace with the flue gas (Figure 8). In addition, to minimize unburned carbon in the flyash, excess oxygen levels, as measured at the economizer outlet, have been increased from the baseline 2.7 percent to approximately 3.5 percent. The increased particulate loading coupled with the increase in gas velocity to the precipitator has adversely affected particulate emissions. A research effort is being organized within the Southern Company to investigate and mitigate the adverse effects of the low NOx burners on precipitator performance. While the particulate emissions issues are being resolved, long-term data collection at reduced loads will continue.

\subsubsection{ECEM Certification}

ECEM certification tests were conducted by Spectrum Systems, Inc. starting June 26, 1991. Reference Method Tests were performed on the stack gas stream and were carried out in accordance with the emission monitoring requirements as set forth by the Environmental Protection Agency on May 25, 1991. The results of these tests ('Table 4) clearly showed that the ECEM is in conformance with all requirements of EPA's "Performance Specifications and Specification Test Procedures for Sulphur Dioxide and Nitrogen Oxides Continuous Emission Monitoring Systems in Stationary Sources". Additional information on the certification of the ECEM can be found in Appendix B. 


\begin{tabular}{|c|c|c|c|c|c|c|c|c|}
\hline \multicolumn{9}{|c|}{ Table 3: Low NOx Burner Short-Term Test Summary } \\
\hline $\begin{array}{l}\text { TEST } \\
\text { NO. }\end{array}$ & DATE & $\begin{array}{l}\text { LOAD } \\
\text { (MW) }\end{array}$ & $\mathrm{MOOS}$ & $\begin{array}{c}\text { STACK } \\
\text { O2 } \\
(\%)\end{array}$ & $\begin{array}{c}\text { ECONO } \\
\mathrm{O} 2 \\
(\%)\end{array}$ & $\begin{array}{c}\text { ECONO } \\
\text { NOx }\end{array}$ & $\begin{array}{c}\mathrm{CO} \\
(\mathrm{PPM})\end{array}$ & COMMENTS \\
\hline 58.1 & $7 / 9 / 91$ & 477 & NONE & 7.1 & 4.6 & 0.69 & 11 & HOH O2 - LOO TEST \\
\hline $58-2$ & $7 / 9 / 91$ & 475 & NONE & 6.5 & 4.1 & 0.65 & 11 & NORMAL. $02 \cdot$ LOI TEST \\
\hline 58.3 & $7 / 9 / 91$ & 473 & NONE & 5.5 & 2.9 & 0.58 & 67 & LOW $02 \cdot$ LOI TEST \\
\hline 59.1 & $7 / 10 / 91$ & 471 & NONE & 7.3 & 5.0 & 0.66 & 12 & HIOH O2 - LO1 TEST \\
\hline 59.2 & $7 / 10 / 91$ & 473 & NONE & 6.4 & 4.0 & 0.60 & 13 & NORMAL. O2 - LOI TRST \\
\hline 59.3 & $7 / 10 / 91$ & 475 & NONE & 5.8 & 3.1 & 0.57 & 26 & LOW O2-LOt TEST \\
\hline $59-4$ & $7 / 10 / 91$ & 474 & NONE & 5.4 & 2.6 & 0.55 & 127 & MINIMUM O2 - LOI TEST \\
\hline 59.5 & $7 / 10 / 91$ & 474 & NONE & 6.3 & 3.7 & 0.61 & 31 & LOWER THAN NORMAL - HVT THST \\
\hline 60.1 & $7 / 11 / 91$ & 393 & NONE & 7.1 & 4.6 & 0.56 & 11 & HOO2 \\
\hline $60-2$ & $7 / 11 / 91$ & 398 & NONE & 6.3 & 3.9 & 0.51 & 13 & NORMAL 02 \\
\hline $60-3$ & $7 / 11 / 91$ & 397 & NONE & 6.0 & 3.5 & 0.49 & 119 & L.OW 02 \\
\hline 60.4 & $7 / 11 / 91$ & 502 & NONE & 6.5 & 4.0 & 0.69 & 4 & HOH LOAD HEAT RATE TEST BY OPC \\
\hline $61-1$ & $7 / 12 / 91$ & 392 & NONE & 7.1 & 4.7 & 0.55 & 6 & REPHAT HI O2 \\
\hline 61.2 & $7 / 12 / 91$ & 392 & NONE & 6,4 & 4.1 & 0.51 & 6 & REPEAT NORMAL 02 \\
\hline $61-3$ & $7 / 12 / 91$ & 390 & NONE & 5.7 & 3.2. & 0.46 & 81 & REPEAT LOW O2 \\
\hline $61-4$ & $7 / 12 / 91$ & 498 & NONE & 6.4 & 3.9 & 0.65 & 15 & HOH LOAD HEAT RATE TEST BY OPC \\
\hline 62.1 & $7 / 13 / 91$ & 289 & $\mathrm{E}$ & 9.2 & 7.1 & 0.62 & 7 & HIOH 02 \\
\hline 62.2 & $7 / 13 / 91$ & 291 & $\mathrm{E}$ & 8.1 & 5.9 & 0.58 & 7 & MEDTUM O2 \\
\hline 62.3 & $7 / 13 / 91$ & 290 & $\mathrm{E}$ & 7.3 & 4.8 & 0.54 & 9 & NORMAL 02 \\
\hline $62-4$ & $7 / 13 / 91$ & 289 & E & - & 4.0 & 0.51 & 14 & LOW O2 ABBREV.TEST \\
\hline 62.5 & $7 / 13 / 91$ & 474 & NONE & 6.9 & 4.3 & 0.64 & 18 & \\
\hline $63-1$ & $7 / 14 / 91$ & 302 & B\&E & 8.1 & 5.8 & 0.50 & 13 & \\
\hline $63-2$ & $7 / 14 / 91$ & 305 & $\mathrm{E}$ & 8.0 & 5.7 & 0.58 & 10 & \\
\hline 63.3 & $7 / 14 / 91$ & 303 & $\mathrm{E}$ & 7.3 & 4.8 & 0.55 & 26 & \\
\hline $64-1$ & $7 / 15 / 91$ & 467 & NONE & 7.0 & 4.6 & 0.66 & 13 & HGH/MII O2, BALANCPD MIILS \\
\hline $64-2$ & $7 / 15 / 91$ & 470 & NONE & 5.9 & 3.3 & 0.58 & 56 & LOW O2, BALANCED MILLS \\
\hline 65.1 & $7 / 16 / 91$ & 470 & NONE & 6.4 & 4.0 & 0.62 & 13 & PERPORMANCE TEST \\
\hline $66-1$ & $7 / 17 / 91$ & 475 & NONE & 6.3 & 3.8 & 0.62 & 13 & PERPORMANCE TEST \\
\hline $66-2$ & $7 / 17 / 91$ & 474 & NONE & 6.5 & 3.8 & 0.63 & 15 & PERPORMANCE TEST \\
\hline $67.1^{\prime}$ & $7 / 18 / 91$ & 472 & NONE & 6.7 & 4.3 & 0.60 & 16 & LOI TEST, HDOH 02, OPEN INNER REG \\
\hline $67.2^{\prime}$ & $7 / 18 / 91$ & 471 & NONE & 6.2 & 3.6 & 0.57 & 171 & LOI TEST, MID O2, SAME INNER REO \\
\hline $67-3^{\prime}$ & $7 / 18 / 91$ & 470 & NONE & 6.1 & 3.5 & 0.58 & 22 & LOI TEST, LOW O2, AND OPEW OUTTER REO \\
\hline $67.4^{\prime}$ & $7 / 18 / 91$ & 465 & NONE & 6.1 & 3.5 & 0.59 & 16 & LOI TEST, L.OW O2, AND CLSE UNDERFIRE AIR TO $25 \%$ \\
\hline $68-1^{\prime}$ & $7 / 19 / 91$ & 460 & NONE & 6.2 & 3.5 & 0.60 & 37 & I.OI TEST, LOWER PRIM AIR FLOW \\
\hline $69-1^{\prime}$ & $7 / 20 / 91$ & 473 & NONE & 5.9 & 3.2 & 0.56 & 19 & LOI TEST, MILL. FINENESS MEASUREMENTS A-MILL \\
\hline $69.2^{1}$ & $7 / 20 / 91$ & 469 & NONE & 5.9 & 3.3 & 0.61 & 15 & LOI TEST, MILL FINENESS MRASUREMENTS P-MILL \\
\hline $70-1$ & $7 / 22 / 91$ & 479 & NONE & 5.9 & 3.3 & 0.68 & 19 & HIOH LOAD PERPORMANCE TEST, REDUUCED PRIM AIR \\
\hline $70-2$ & $7 / 22 / 91$ & 470 & NONE, & 6.0 & 3.6 & 0.66 & 32. & HIOH LOAD PERHOR.MANCR TZST, REDUCED PRIM AIR \\
\hline 71.1 & $7 / 23 / 91$ & 473 & NONE & 6.0 & 3.5 & 0.66 & 15 & HIOH LOAD PURP, TEST, OPENED OUTER REO TO $90 \%$ \\
\hline 71.2 & $7 / 23 / 91$ & 465 & NONE & 5.9 & 3.5 & 0.68 & 15 & HICH LOOAD PERP. TRST, AND REDUCED PRIM AIR \\
\hline $72-1$ & $7 / 24 / 91$ & 477 & NONE & 6.1 & 3.4 & 0.65 & 17 & HIGH LOAD PIRPPORMANCH TEST, REDUCED PRIM AIK \\
\hline $73-1$ & $7 / 26 / 91$ & 388 & NONE & 6.5 & 4.1 & 0.55 & 11 & MID LOAD PERPORMANCR TEST, HIOH O2 \\
\hline 73.2 & $7 / 26 / 91$ & 389 & NONE & 6.5 & 4.1 & 0.55 & 7 & MID LOAD PERFORMANCI TEST, HIOH O2 \\
\hline 74.1 & $7 / 27 / 91$ & 403 & NONE & 6.0 & 3.8 & 0.55 & 8 & MID LOOAD PERPORMANCI TEST, HIGH O2 \\
\hline 74.2 & $7 / 27 / 91$ & 405 & NONE & 5.8 & 3.6 & 0.57 & 9 & MID LOAD PERFORMANCX TXST, HIGH O2 \\
\hline $75-1$ & $7 / 28 / 91$ & 299 & $\mathrm{E}$ & 6.6 & 4.3 & 0.47 & 8 & LOWMID LOAD PERPORMANCY TPST \\
\hline 76.1 & $7 / 28 / 91$ & 298 & $\mathrm{E}$ & 6.7 & 4.5 & 0.48 & 8 & L.OW/MID LOAAD PERPORMANCE TEST \\
\hline
\end{tabular}




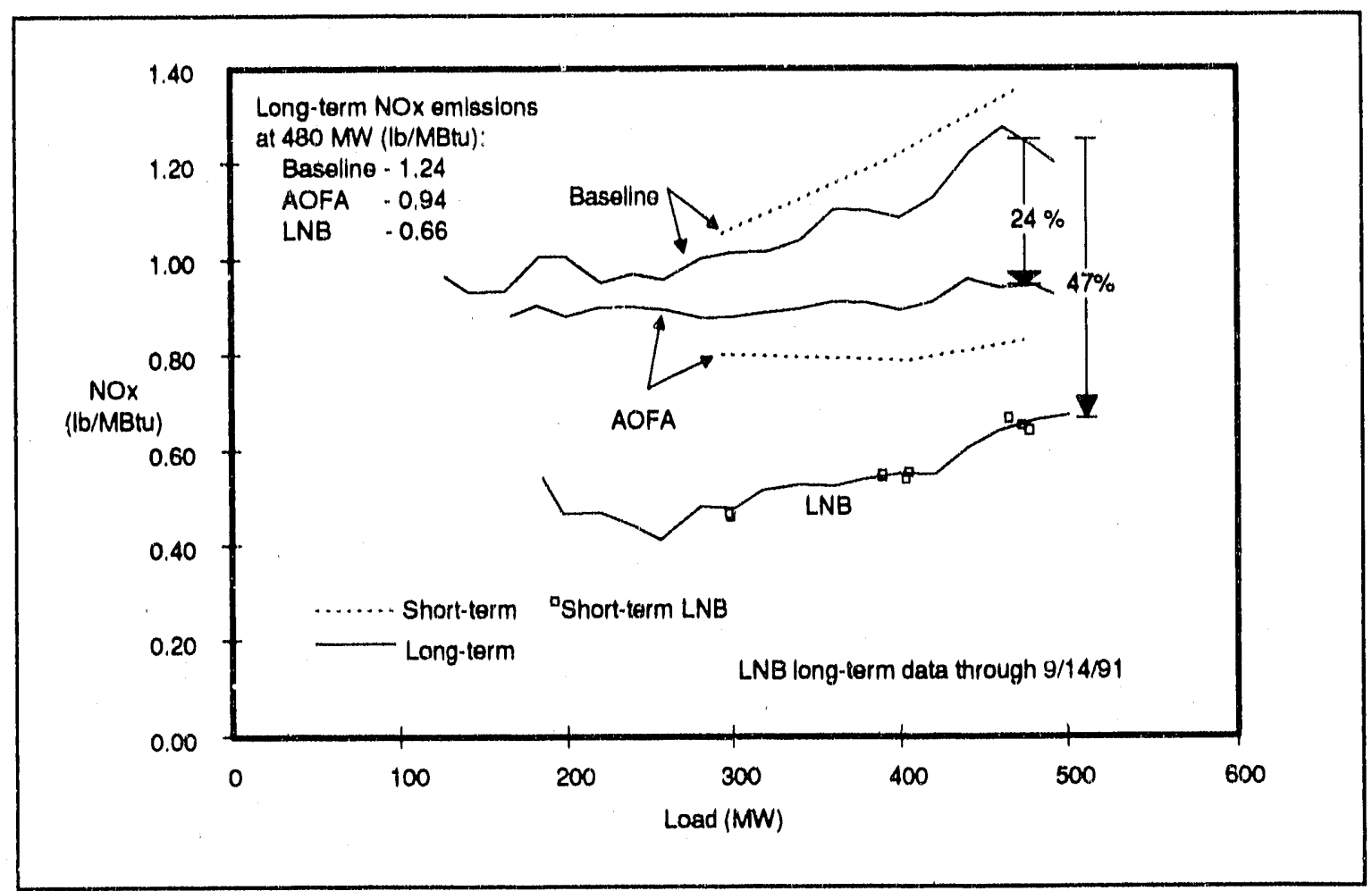

Figure 4: $\quad \mathrm{NO}_{\mathrm{X}}$ Emissions

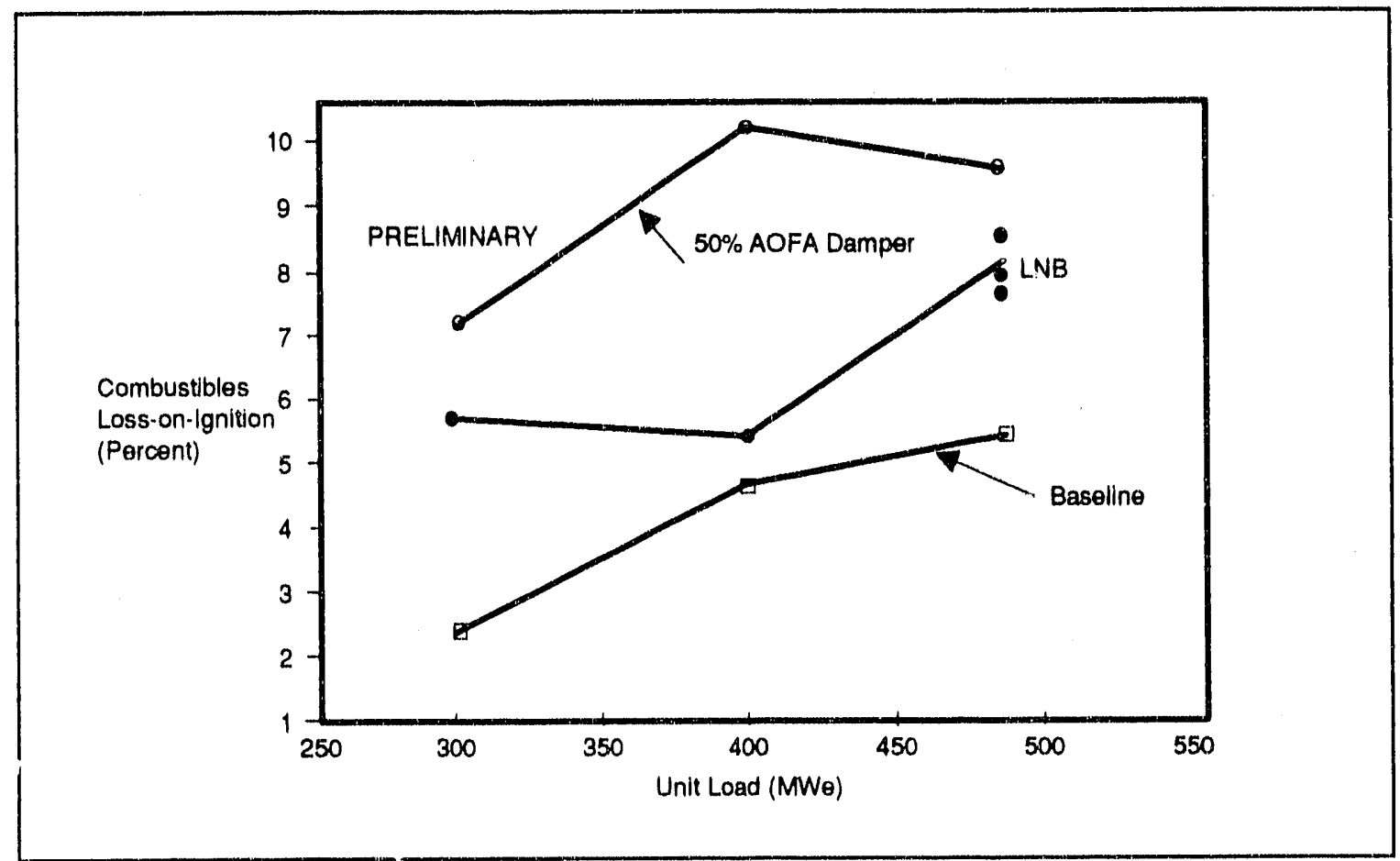

Figure 5: $\quad$ Flyash Combustibles Loss-on-Ignition 


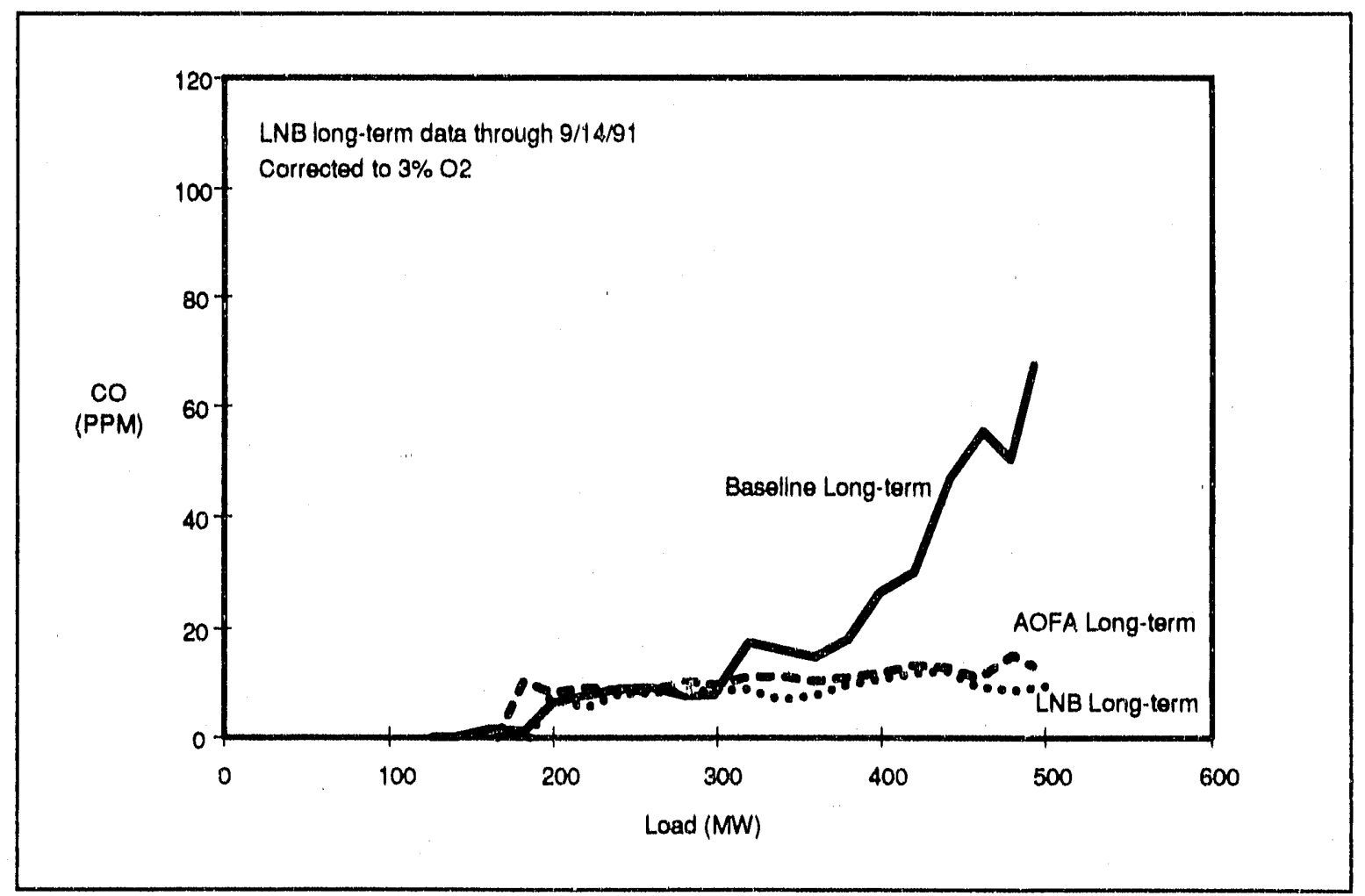

Figure 6: CO Emissions

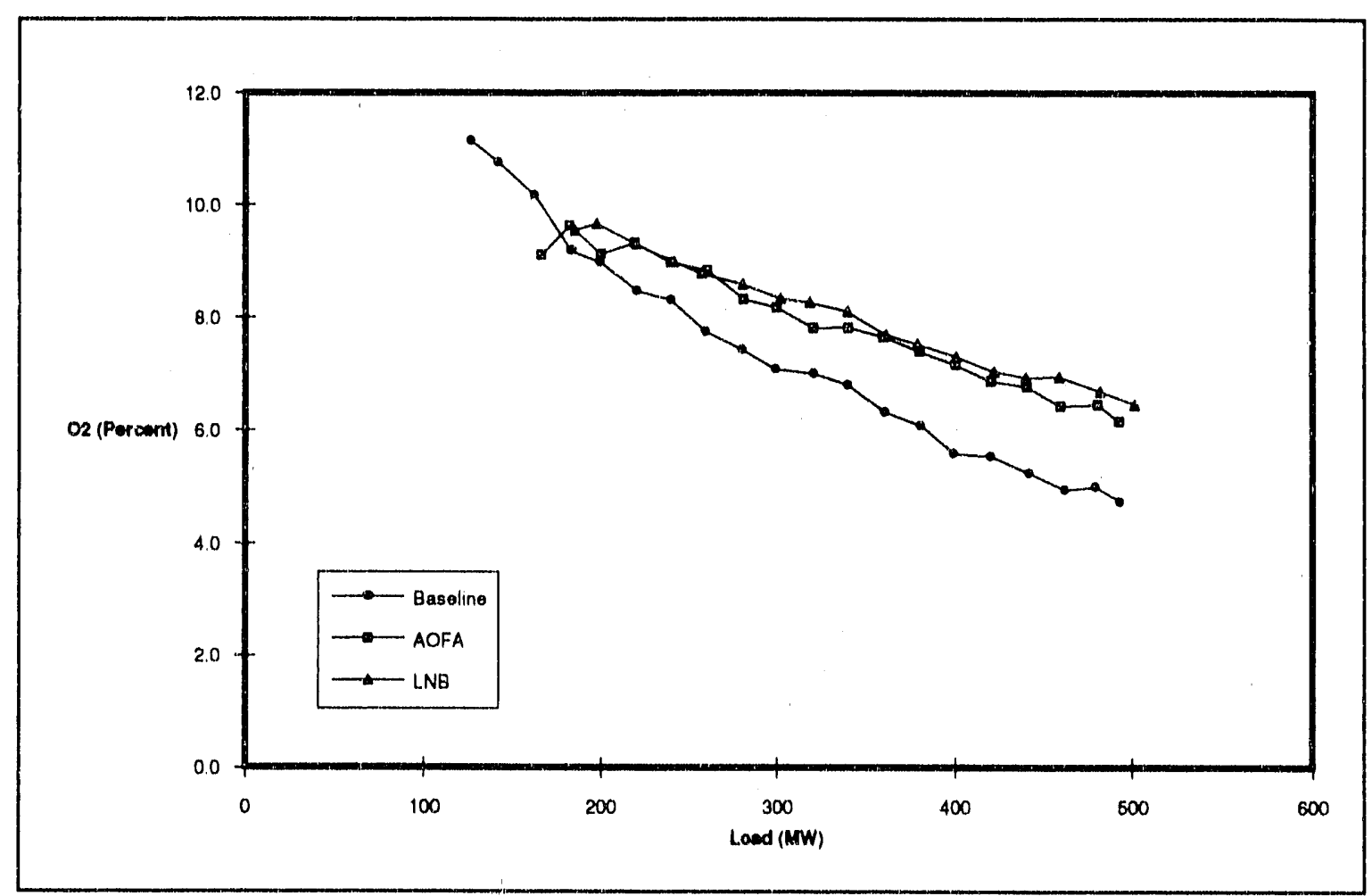

Figure 7: $\quad$ Stack $\mathrm{O}_{2}$ Levels 


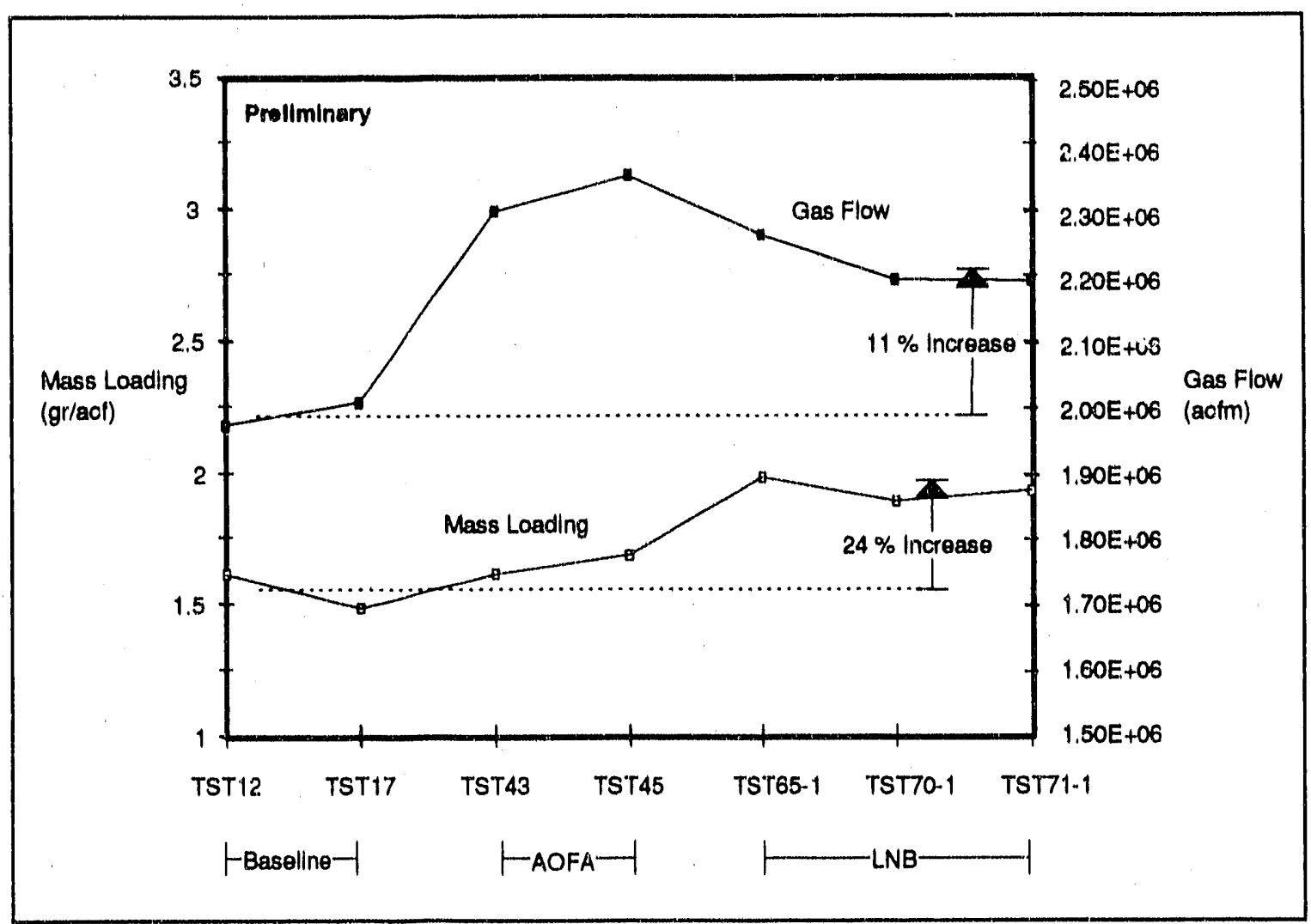

Figure 8: $\quad$ ESP Inlet Particulate Mass Loading and Gas Flow Rate

\begin{tabular}{|c|c|c|c|c|}
\hline \multicolumn{2}{|c|}{ Table 4: ECEM Certification Tests Results - June - July 1991 } \\
\hline Test & SO2 & NOx & O2 & EPA Specs. \\
\hline Zero Drift (24 hr) & $0.92 \%$ & $0.60 \%$ & - & Less than or equal to 2.5\% / day \\
\hline & - & - & $0.20 \%$ & Less than or equal to 0.5\% / day \\
\hline Calibration Drift (24 hr) & $-0.88 \%$ & $-0.48 \%$ & - & Less than or equal to $2.5 \% /$ day \\
\hline & - & - & 0.00 & Less than or equal to 0.5\% / day \\
\hline Relative Accuracy & $11.54 \%$ & $2.62 \%$ & - & Less than or equal to $20 \%$ \\
\hline
\end{tabular}




\section{FUTURE PLANS}

The following is a quarterly outline of the activities scheduled for the remainder of the project:

\begin{tabular}{|c|c|}
\hline \multicolumn{2}{|c|}{ Future Plans } \\
\hline Quarter & Activity \\
\hline Fourth Quarter 1991 & $\begin{array}{l}\text { - Complete Long-Term LNB Tests } \\
\text { - Verification Tests of the LNB's } \\
\text { - Diagnostic Tests of the LNB's+AOFA } \\
\text { - Begin Long-Term LNB+AOFA Tests }\end{array}$ \\
\hline First Quarter 1992 & $\begin{array}{l}\text { - Performance Tests of the LNB's+AOFA } \\
\text { - Complete Long-Term LNB+AOFA Tests } \\
\text { - Verification Tests of the LNB's+AOFA } \\
\text { - Begin Final Reporting } \\
\end{array}$ \\
\hline Second Quarter 1992 & $\begin{array}{l}\text { - Complete Final Reporting } \\
\text { - Disposition } \\
\text { - Project Completion }\end{array}$ \\
\hline
\end{tabular}




\section{ACKNOWLEDGEMENTS}

The following project participants are recognized for their dedicated efforts toward the success of the wall-fired low $\mathrm{NO}_{\mathbf{x}}$ demonstration: Mr. Ernie Padgett, Georgia Power Company, and Mr. Mike Nelson, Southern Company Services, for their coordination of the design and retrofit efforts and Mr. Jose Perez, full-time Instrumentation Specialist from Spectrum Systems, Inc. Also Messrs Jim Witt and Jimmy Horton of Southern Company Services for design, procurement, and installation of the instrumentation systems. The following companies have provided outstanding testing and data analysis efforts: Energy Technology Consultants, Inc., Flame Refractories, Inc., Southern Research Institute, W. S. Pitts Consulting, and Radian Corporation. Finally, the support from Mr. Art Baldwin, DOE ICCT Project Manager, and Mr. David Eskinazi, EPRI Project Manager, is greatly appreciated. 
APPENDIX A

Phase 3 Long "Term ${ }^{\text {NO }}{ }_{x}$ Emissions and Generation 
之. 怘总

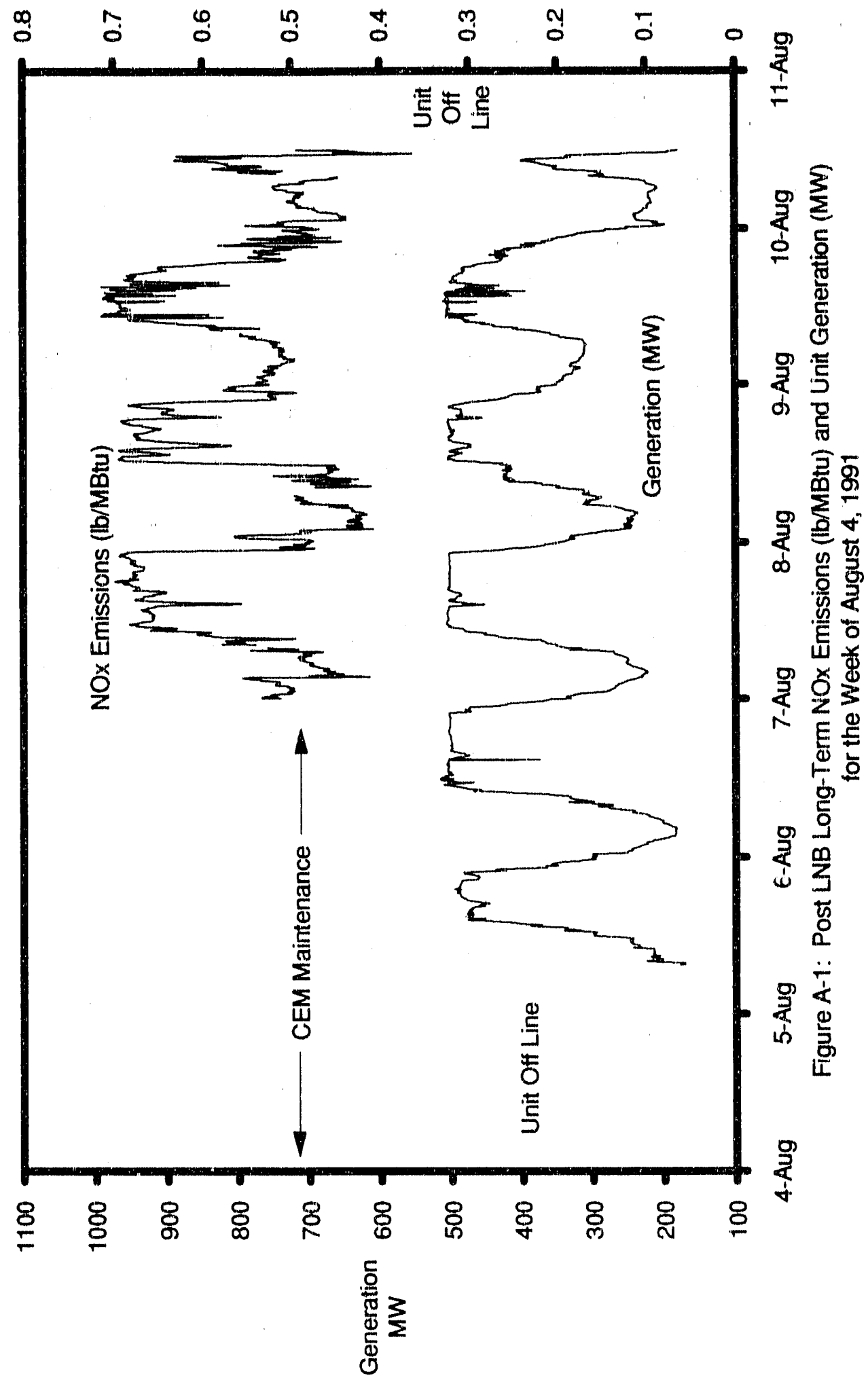




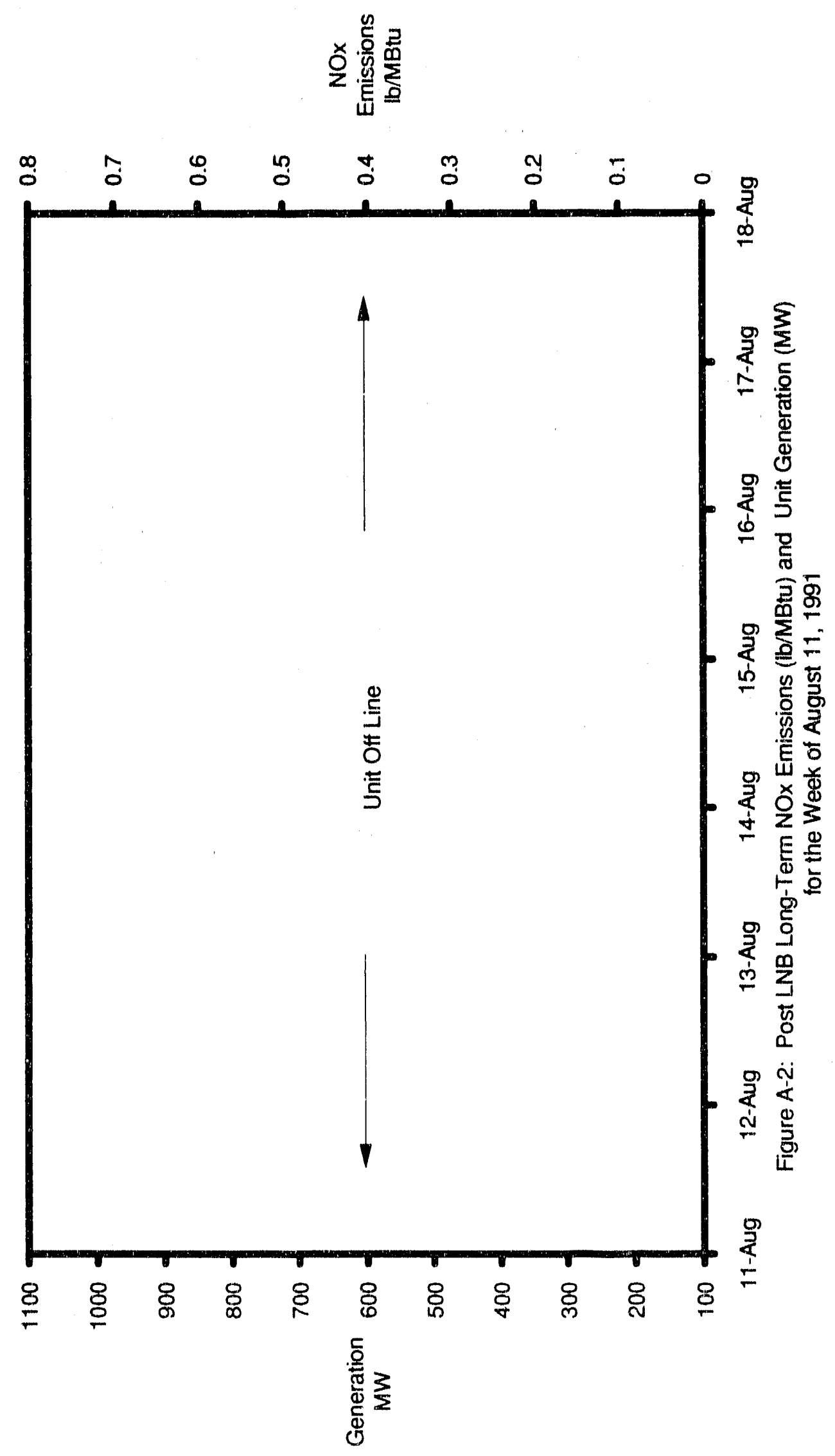




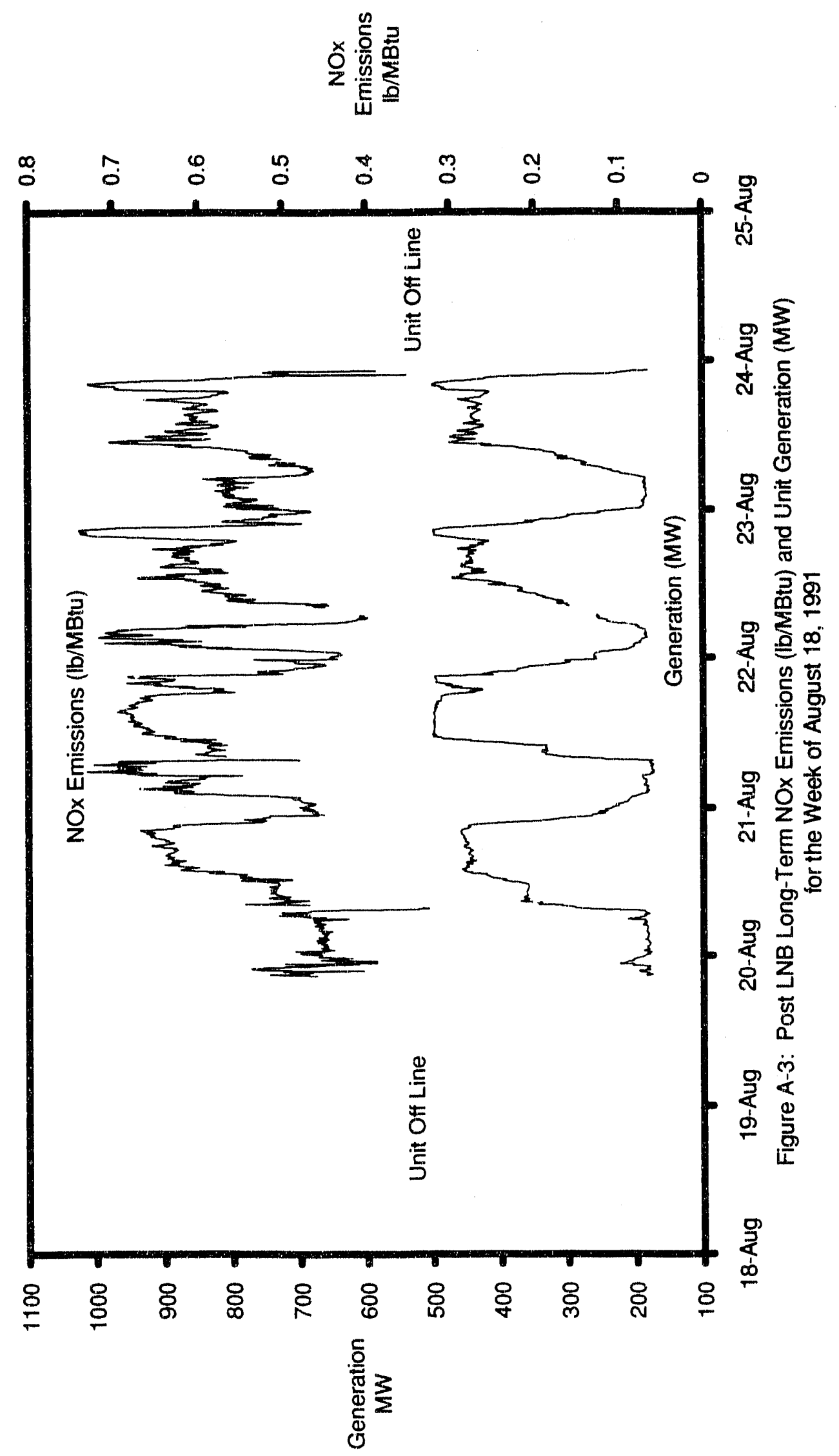




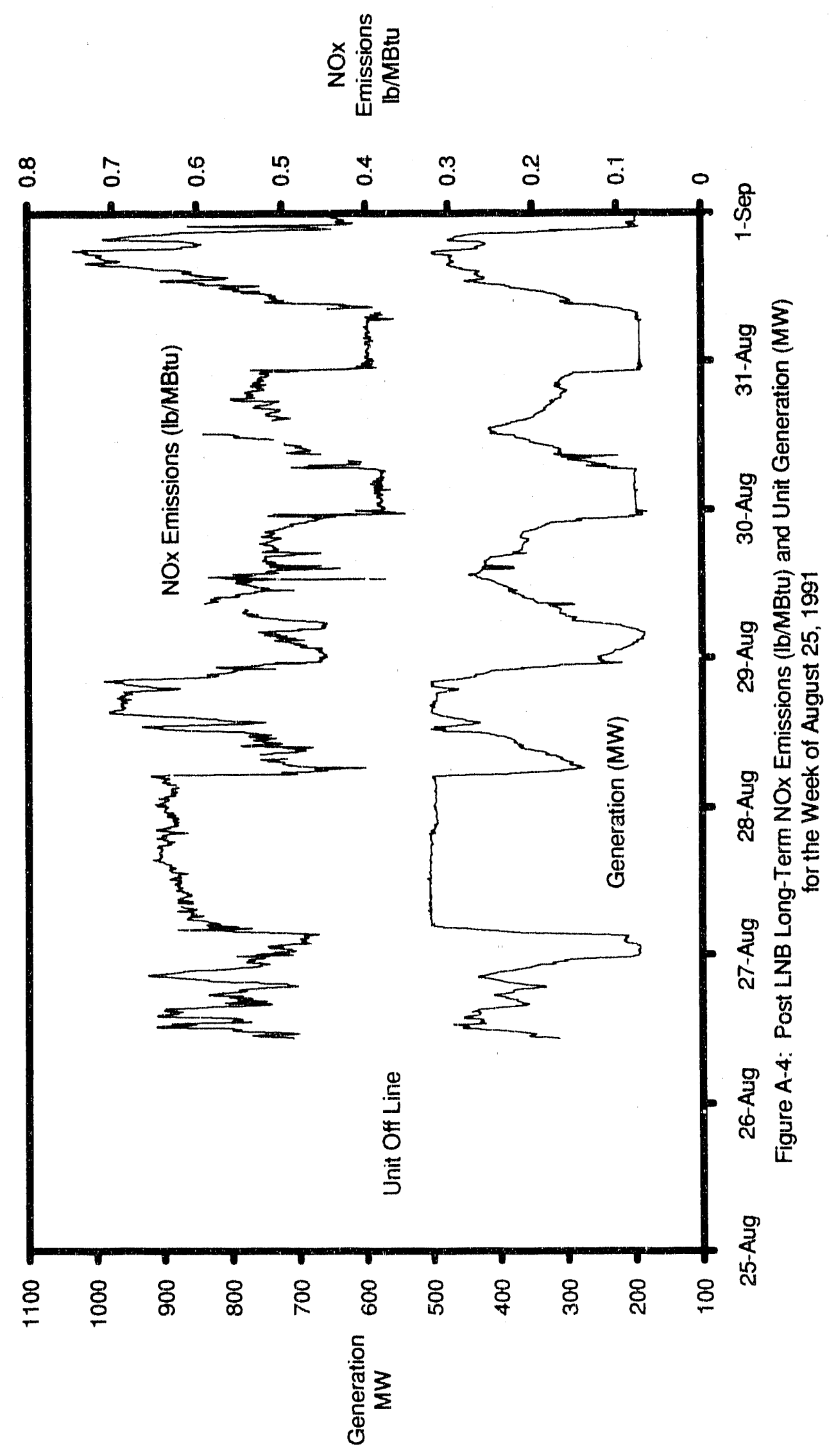


乫总

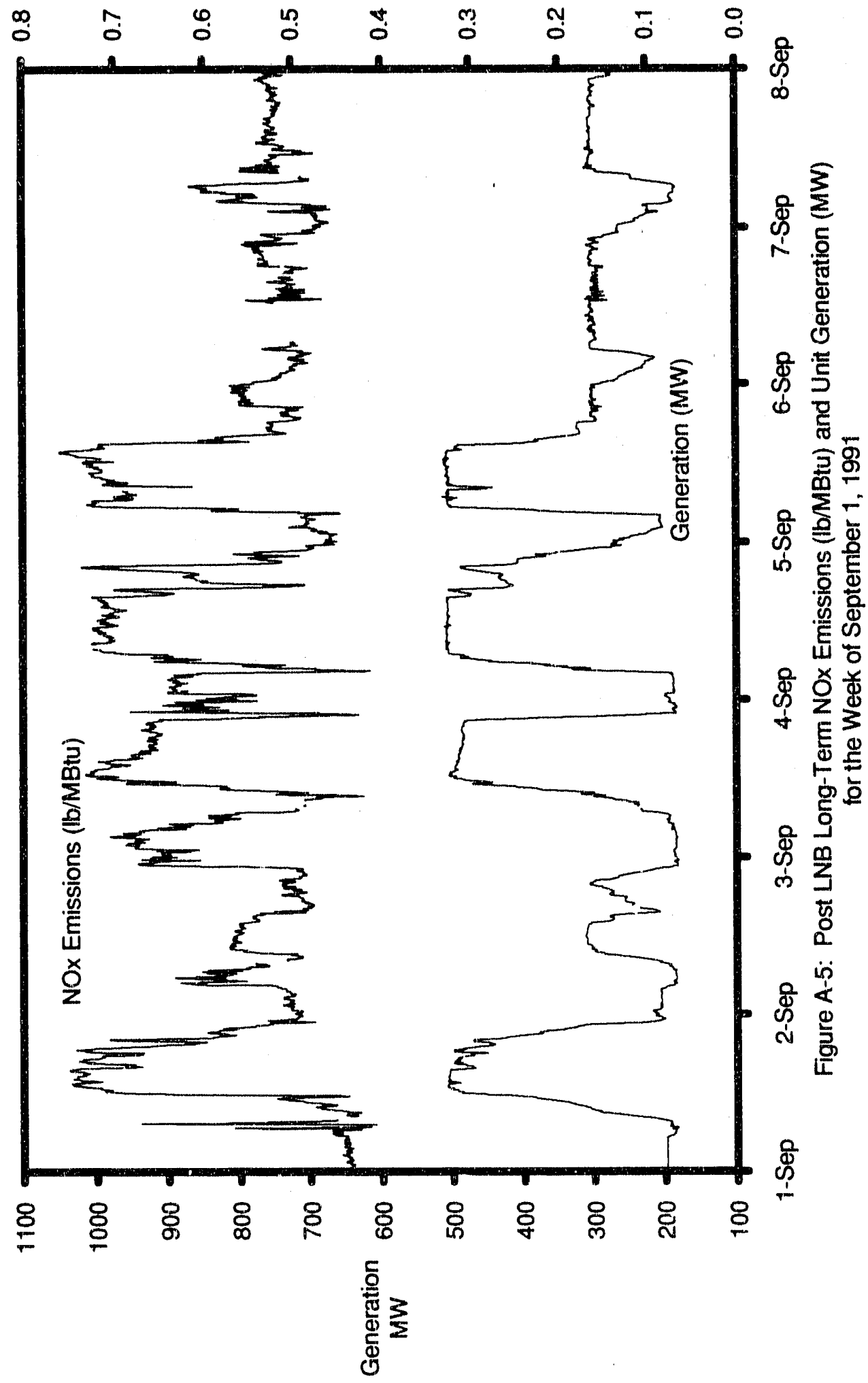




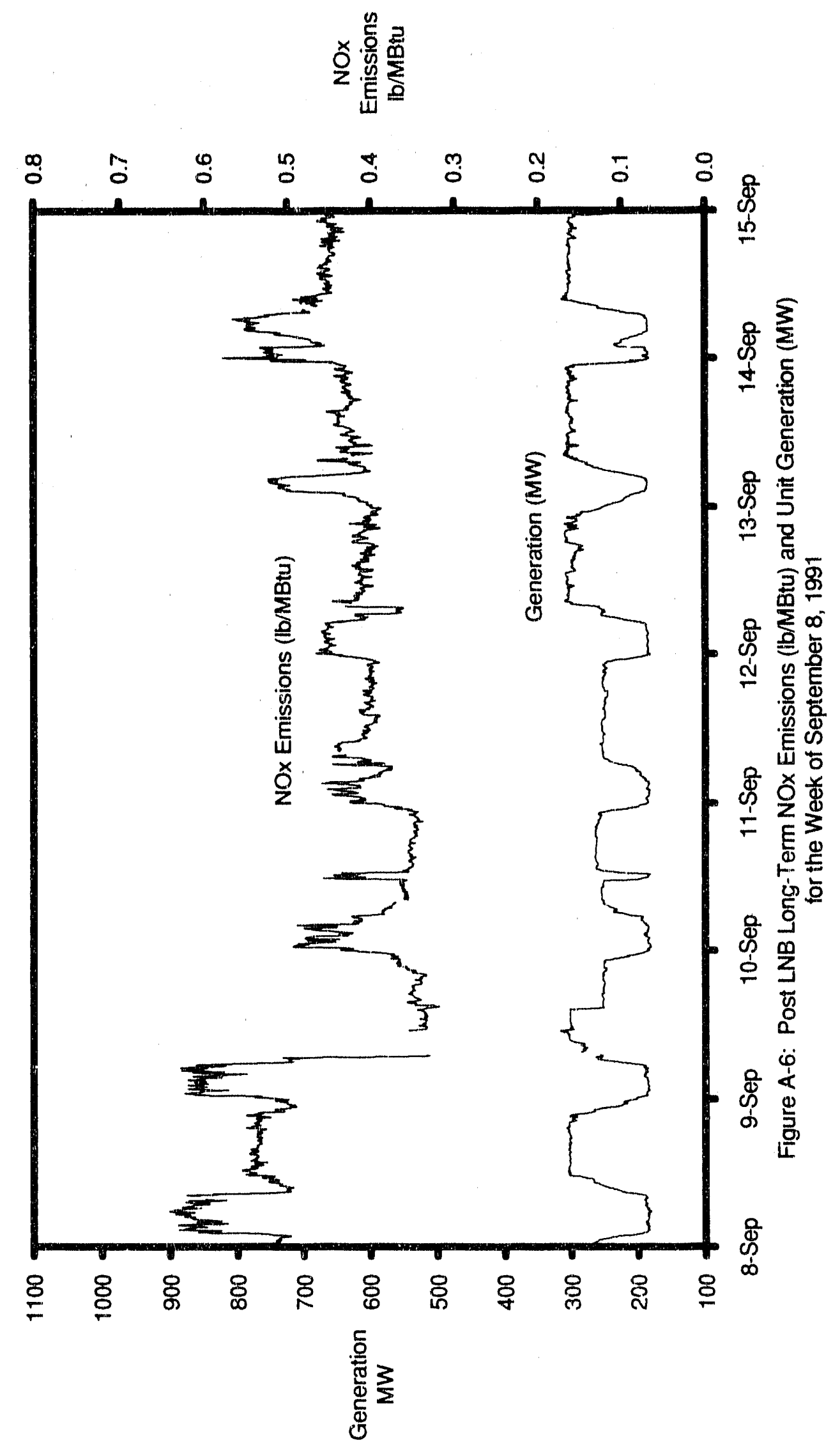




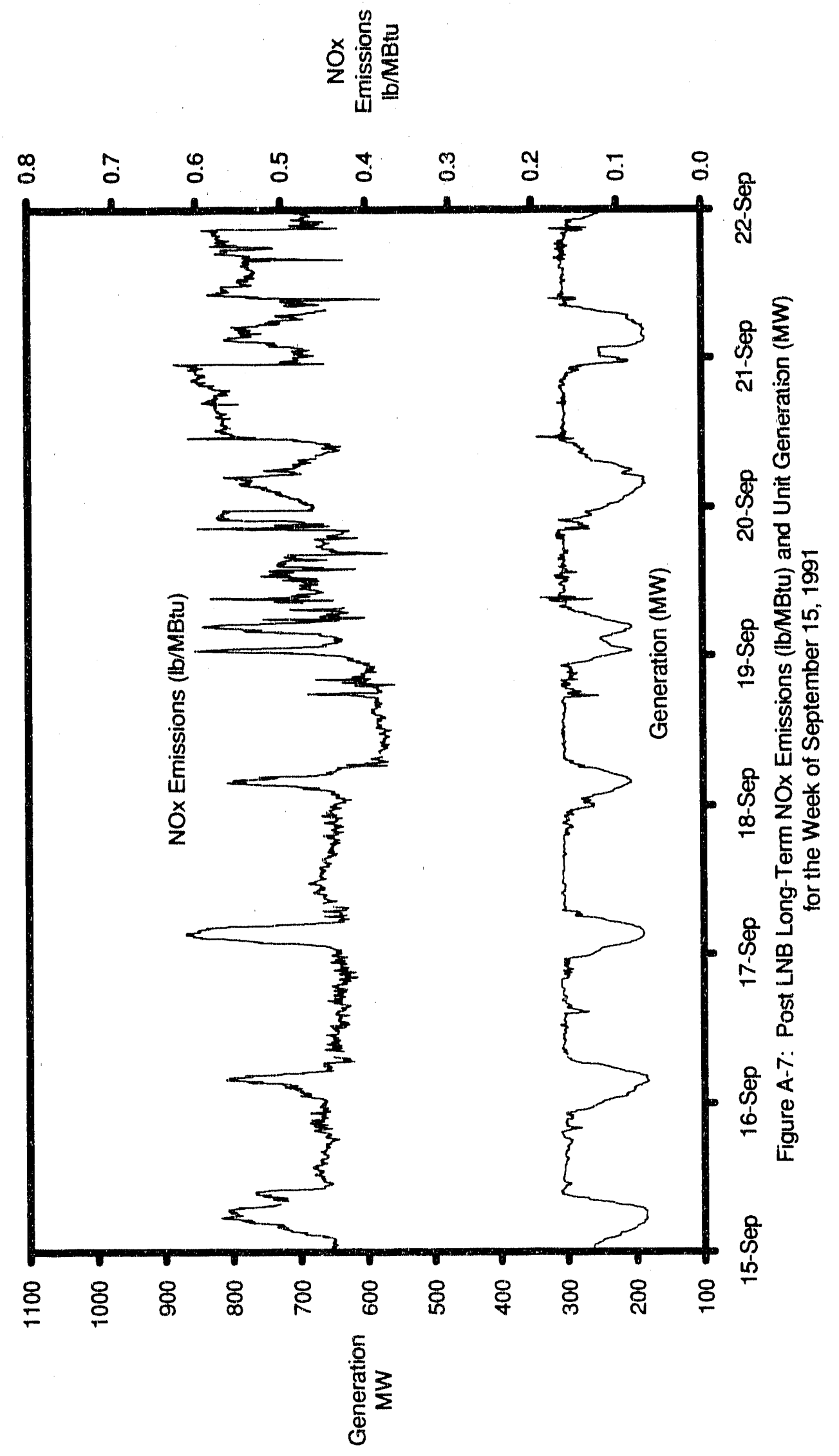




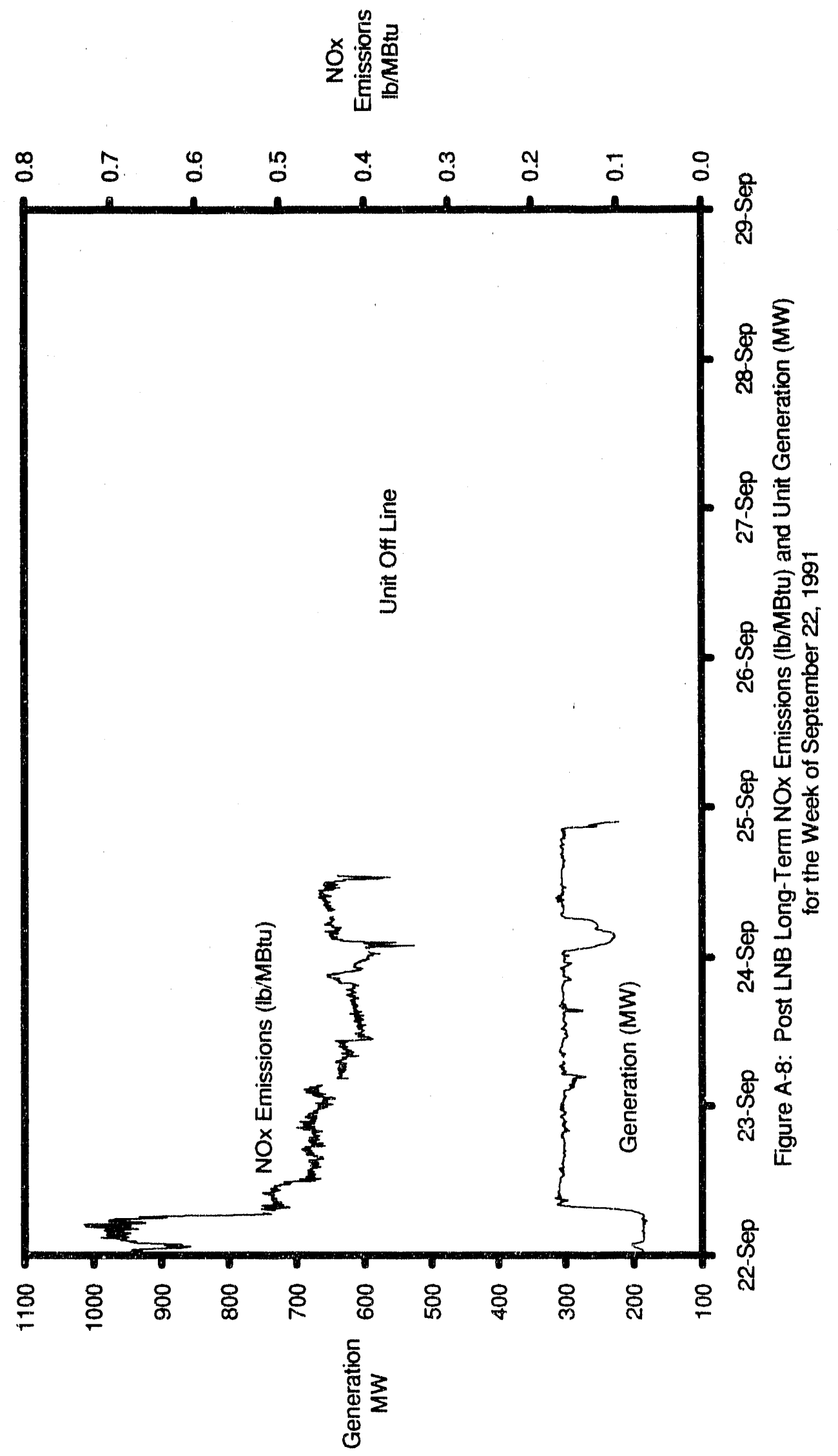


APPENDIX B

Phase 3 CEM Certification Report 


\title{
CERTIFICATION REPORT
}

\author{
UNIT * 4 \\ GEORGIA POWER COMPANY \\ PLANT HAMMOND
}

July 25,1991

Prepared by:

Spectrum Systems, Inc.

3410 West Nine Mile Road

Pensacola, Florida 32526

(904) 944-3392 


\section{CERTIFICATION TESTING \\ UNIT \#4 \\ GEORGIA POWER COMPANY \\ PLANT HAMMOND}

JULY 25,1991

Prepared by:

Spectrum Systems, Inc.

Pensacola, Florida 


\section{TABLE OF CONTENTS}

I. INTRODUCTION

II. INSTALLATION DESCRIPTION AND START UP

III. SUMMARY

IV. DISCUSSION OF RESULTS

CALIBRATION DRIFT TEST

CALIBRATION ERROR TEST

RELATTVE ACCURACY

LOG OF OPERATIONS

PERFORMANCE TEST RESULTS

V. APPENDIX

NOTICE OF FIELD CERTIFICATION

REPORT CERTIFICATTON

MATHEMATICAL EXPLANATION

REFERENCE METHOD TEST REPORT

APPENDIX A - CALCULATION OF A VERAGE EMISSIONS

APPENDIX B - SYSTEM CALIBRATION BIAS AND DRIFT CALCULATIONS

APPENDIX C - MEASUREMENT SYSTEMS PERFORMANCE TESTS

APPENDIX D - CONTINUOUS EMISSIONS MONITORING SYSTEMS OUTPUT DATA

APPENDIX E - STRIP CHART RECORDINGS

APPENDIX F - CALIBRATION GAS CERTIFICATES OF ANALYSIS

APPENDIX G - EPA TEST METHODS AND SPECIFICATIONS 


\section{INTRODUCTION}

Spectrum Systems, Inc. was contracted by Georgia Power Company to conduct a Performance Evaluation of the Plant Hammond Continuous Emission Monitoring Systems (CEMS), comprised of an Ametek Model WDGIII O2 Analyzer, Serial Number CO58405(B)-1; Western Research Model 721-AT SO2 Analyzer, Serial Number 89721AT2-7543-3; and a Thermo Environmental Model 10 NOx Analyzer, Serial Number 10 A/R-25864-222. The KVB extractive system monitors the exhaust gas duct as well as several intermediate ducts, on command. Reference Method Tests were performed on the stack gas stream to determine instrument accuracies. The installation was made on the multi-fuel boiler located on Unit \#4 at the Plant Hammond facility. This certification was performed in accordance with the emission monitoring requirements as promulgated on May 25, 1984, by the Environmental Protection Agency. Field tests were conducted from June 26,1991 , through July 19,1991 . The instrument operated continuously throughout the operational test period without maintenance or service. During the relative accuracy test period, the boiler was operated at greater than $50 \%$ of normal load. Results in this report include data from a diluent monitor since reporting is required in a mass emission output format. The diluent monitors were also certified during this test.

\section{INSTALLATION DESCRIPTION}

The instruments were installed on the exhaust stack and main exhaust duct of the Unit \#4 Boiler located at the Plant Hammond facility. Further installation information can be obtained from the affected facility. The initial start-up was on 11/2/89 for the KVB system. The effluent gases are assumed to be representative in accordance with para. 3.1.1. of the referenced specification since the monitor location is more than eight diameters downstream of the nearest control device and in the centroid into the effluent stream. These monitoring 
systems are used to evaluate the effects of NOx reduction procedures under test at the facility.

\section{SUMMARY}

Test results of the Performance Evaluation are presented in Table III-1 A and B. These results are based on data obtained in Rome, Georgla during normal operation at the facility. The test results clearly show that the KVB continuous emissions monitor is in conformance with all requirements of "Performance Specifications and Specification Test Procedures for Sulphur Dioxide and Nitrogen Oxides Continuous Emission Monitoring Systems in Stationary Sources."

\section{DISCUSSION OF RESULTS}

\section{Calibration Drift Test}

Calibration drift was tested in accordance with paragraph 1 of Performance Specification 2. Both SO2/NOx monitors are designed to provide automatically timed zero and span calibration checks at 24 hour intervals throughout the required 7 consecutive days. The zero value is determined by mechanically introducing to the probe measurement cavity or sample probe a supply of zero air, thereby producing a zero condition that checks the analyzer's internal components and all electronic circuitry includirig the radiation source and detector assembly. The span of the system is checked with a calibration gas equivalent to between a 50 and 90 percent deflection of span concentration, utilizing the probe measurement cavity in a manner similar to that described above. Adjustments were not made on the gas monitor or the diluent monitor during the Calibration Drift Test. Twentyfour (24) hour results were calculated by taking the daily recorded monitor response and 
subtracting this reading from the reference value. Daily calibration drift tests are contained In the reports entitled, "Plant Hammond Unit 4 Clean Coal Project", Valw Croup 199, 200 and 201, taken from the plant reporting data acquisition system and found in Appendix D of this report.

\section{Calibration Drift Test Results}

Results of the two (2) point Calibration Drift Test are as follows:

Sulphur Dioxide and Nitrogen Oxide stack gas monitor and the oxygen diluent monitor calibration drift for the seven (7) consecutive day period did not exceed $2.5 \%$ of the zero or span value for pollutant parameters, or $0.5 \%$ oxygen by volume for the diluent monitor for any given day. Drift test results are displayed in tabular formats (see Table IV-1 and IV-1A through IV-3 and IV-3A).

Federal R gister specifications permit calibration drift to be less than equal to $2.5 \%$ of span for sulphur dioxide and nitric oxide and $0.5 \% \mathrm{O} 2$ by volume for diluent oxygen for each 24 hour period of the seven (7) day calibration drift test. The test data used in calculating these results is presented on Table IV-1 and IV-1A through IV-3 and IV-3A.

\section{Calibration Error Test}

A calibration error test or cylinder gas audit was performed in accordance with the QA guid:line contained in the Title 40 Part 60 Appendix F of Code of Federal Regulations. This test was used to assess the accuracy of each TCEMS prior to the reference method testing procedures. No adjustments were made to the TCEMS as a result of the gas audits. 


\section{Relative Accuracy}

Relative Accuracy is defined in the Federal Register as "the degree of correctness with which the continuous monitoring system yields the value of gas concentration of a sample relative to the value given by a defined reference method." The defined reference method, in this case, is EPA Reference Methods $3 \mathrm{~A}, 6$ and $7 \mathrm{E}$. Nine sets of tests were performed beginning on June 27, 1991, at a point established in accordance with Section 7.1 of the Eederal Register. Additional details can be found in the appendix of this report.

The accuracy is reported as an error and is the sum of the absolute mean value of the difference between the reference test and the combined readings, plus a $95 \%$ confidence interval of the differences, expressed as a percentage of the mean combined reference value. The analyzer's average response was determined from the computer printouts corresponding to the time period the relative accuracy tests were performed.

When using computer printouts for comparisons to the reference methods, one minute instrument averages were used, corresponding to the time frame of stack gas samples. The method for arriving at the comparison of LBS/MBTU is obtained by using a formula that calculates the ernission output based on raw PPM, the percent of oxygen and moisture factor. The formulas used for conversion are explained in the Appendix, under the section entitled, "Mathematical Explanation."

The relative accuracy is displayed in Table IV-4 and IV-5. Federal Register specifications limit the allowable error to $20 \%$ of the mean calculated reference method value. 
DOE. SOLTHERA COMPANY SERYICES, INC

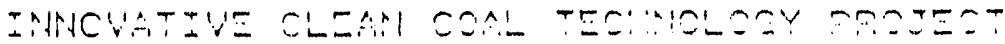

CEORGIA POLEP - PLANT HAMWONO - UNIT FOUR

\section{EQUIPMENT INUENTCFY - CEM SYETEM}

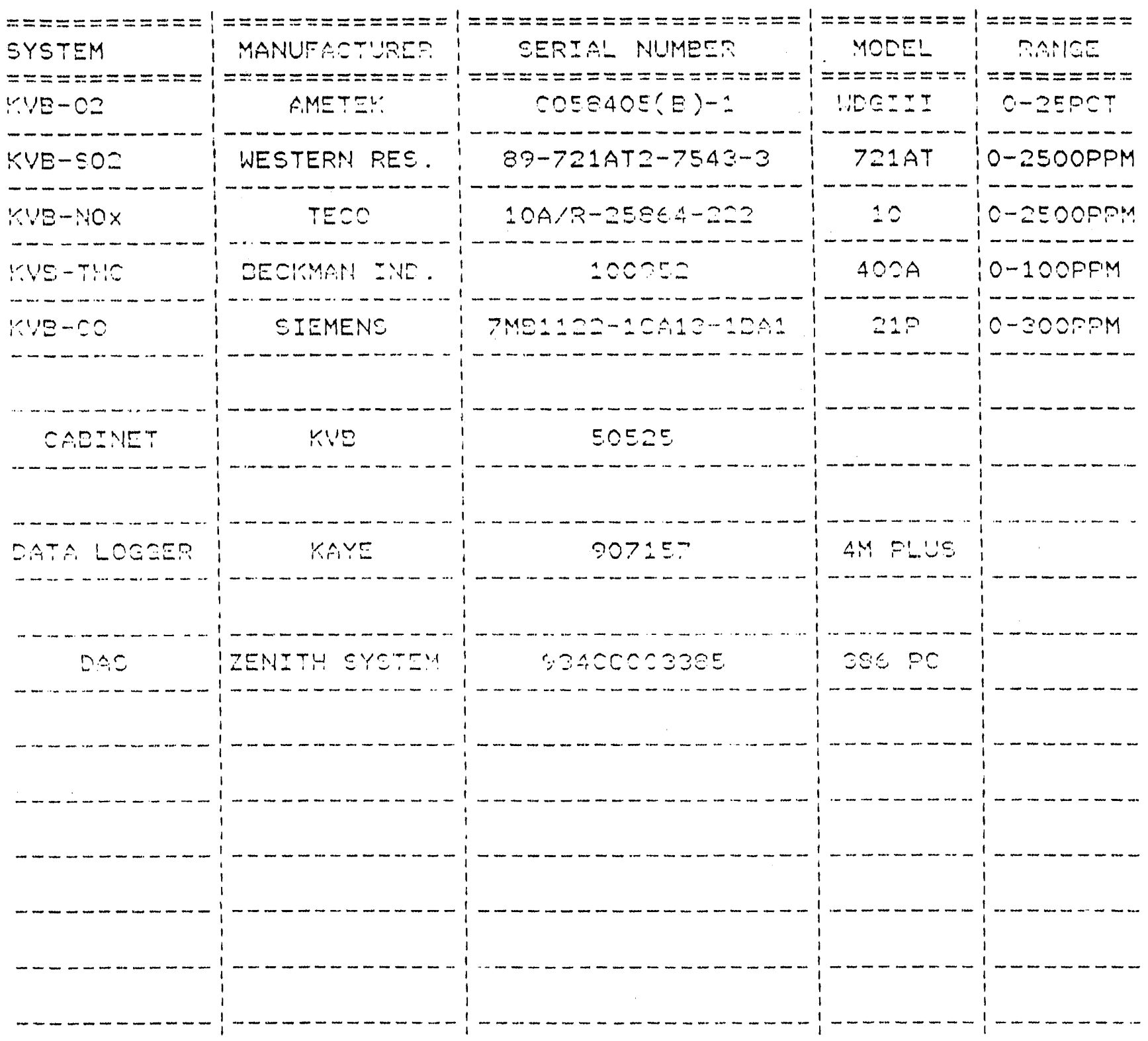




\section{LOG OF OPERATIONS}

KVB SYSTEM S/N 50525

Model and Manufacturer

Instrument Serial Number

Diluent Serial Number

Initial Start-up

Start of Performance Calibration

Start of Calibration Drift Test

End of Calibration Drift Test

Start of Relative Accuracy Test

End of Relative Accuracy Test
KVB Model 50 Extractive

50525 - Cabinet

89-721 AT2-7543-3-SO2

10 A/R-25864-222-NOx

Ametek CO58405(B)-1

$11 / 02 / 89$

07/12/91

$07 / 12 / 91$

07/19/91

06/27/91

$06 / 27 / 91$ 
TABLE III-1A

PERFORMANCE TEST RESULTS

KVB SYSTEM (S/N 50525)

\section{Munitor Performance EPA Specificarions}

SO2 Instrument Serial Number

NOx Instrument Serial Number

Diluent Serial Number

Calibration Period

NOx Analyzer

Cal. Drift (Lo pt. 0-20\%)

SO2 Analyzer

Cal. Drift (Lo pt. 0-20\%)

Diluent Oxygen Analyzer

(Downscale checkpoint)

SO2 Analyzer

Cal. Drift (Hi pt. 50-100\%)

NOx Analyzer

Cal. Drift (Hi pt. 50-100\%)

Diluent Oxygen Analyzer

(Upscale checkpoint)

System Relative Accuracy

computed in lbs/Mbtu (SO2)

System Relative Accuracy computed in lbs/Mbtu (NOx)
89-721AT2-7543-3

10 A/R-25864-222

$\operatorname{CO584()5(B)-1}$

seven (7)

consecutive days

seven (7)

consecutive days

\section{$0.00 \%$ largest daily less than or equal to difference (NOx) $2.5 \%$ span per day}

$0.92 \%$ largest daily less than or equal to difference (NOx) $\quad 2.5 \%$ span per day

$0.20 \%$ largest daily less than or equal to difference $(\mathrm{O} 2) \quad 0.5 \% \mathrm{O} 2$ by volume per day

$-0.88 \%$ largest daily less than or equal to difference (NOx) $2.5 \%$ span per day

$-0.48 \%$ largest daily less than or equal to difference (NOx) $2.5 \%$ span per day

$0.00 \%$ largest daily less than or equal to difference $(\mathrm{O} 2) \quad 0.5 \% \mathrm{O} 2$ by volume per day

$11.547 \%$ less than or equal to $20 \%$

$2.627 \% \quad$ less than or equal to $20 \%$ 
CALIBRATION DRIFT DETERMINATION

DOE/SOUTHERN COMPANY SERVICES, INC.

INNOVATIVE CLEAN COAL TECHNOLOGY PROJECT'

GEORGIA POWER COMPANY - PLANT HAMMOND UNIT FOUR

SYSTEM

MANUFACTURER

MODEL

SERIAL NUMBER
KVB-SO2

WESTERN RESEARCH

$721-A T$

$89-721$ AT2 $2-7543-3$
GAS

SPAN RANGE $2500 P P M$ OPERATOR
$\mathrm{SO} 2$ $2500 P P M$ JOSE PEREZ

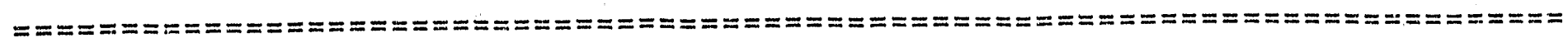
SPAN DRIFT

\begin{tabular}{|c|c|c|c|c|c|c|}
\hline & & & CAL IBRATION & MONITOR & IFFERENCE & PERCENT OF \\
\hline DAY & DATE & TIME & VALUE PPM & IVALUE PPM & IN PPM & SPAN VALUE \\
\hline TART & |12-Jul-91 & $108: 00 \mathrm{AM}$ & 1490 & 1490 & 0 & 0.00 \\
\hline 1 & i3-Jul & $06: 15$ AM & 16 & 1468 & -22 & -0.88 \\
\hline 2 & 14-Ju1-91 & $06: 10 \mathrm{AM}$ & 14 & 1469 & -21 & $-0.84 \%$ \\
\hline 3 & $15-J u 1-91$ & $08: 25$ AM & 1490 & 1473 & -17 & -0.68 \\
\hline 4 & $16-J u 1-91$ & 106:25 AM & 1490 & 1486 & -4 & -0.1 \\
\hline 5 & $\mid 17-J u 1-91$ & $106: 10 \mathrm{AM}$ & 1490 & 1468 & -22 & -0.8 \\
\hline 6 & 18-Jul-91 & 105:55 AM & 1490 & 1484 & -6 & -0.2 \\
\hline 7 & $19-J u 1-91$ & $05: 55$ AM & 1490 & 1510 & 20 & 0. \\
\hline
\end{tabular}

$== \pm==ニ==$
ZERO DRIFT

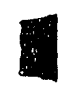

$\begin{array}{l:l:l:l:} & & \text { ICALIBRATION } & \text { MONITOR } \\ \text { DAY } & \text { DATE } & \text { TIME } & \text { VALUE PPM }\end{array}$

IDIFFERENCE IPERCENT OF

\begin{tabular}{c|c|c|c} 
START & $12-J U 1-91$ & $07: 45$ & $A M$ \\
1 & $13-J U 1-91$ & $06: 05$ & $A M$ \\
2 & $14-J U 1-91$ & $06: 00$ & $A M$ \\
3 & $15-J U 1-91$ & $08: 15$ & $A M$ \\
4 & $16-J u 1-91$ & $06: 15$ & $A M$ \\
5 & $17-J u 1-91$ & $06: 00$ & $A M$ \\
6 & $18-J u 1-91$ & $05: 45$ AM \\
7 & $19-J U 1-91$ & $05: 45$ AM
\end{tabular}

$\begin{array}{r:r}0 & 0 \\ 0 & 9 \\ 0 & 10 \\ 0 & 5 \\ 0 & 0 \\ 0 & 14 \\ 0 & 3 \\ 0 & 23\end{array}$

IN PPM ISPAN VALUE

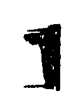

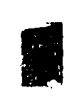

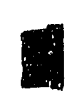

$\%$ SPAN $=$ ( (INSTRUMENT RESPONSE - EXPECTED CONCENTRATION)/SPAN VALUE)*10O 
CALIBRATION DRIFT DETERMINATION

DOE/SOUTHERN COMPANY SERVICES, INC.

INNOVATIVE CLEAN COAL TECHNOLOGY PROJECT

GEORGIA POWER COMPANY - PLANT HAMMOND UNIT FOUR

SYSTEM

MANUFACTURER

MODEL

SERIAL NUMBER
KVB-NOX

THERMO ENVIRONMENTAL

10

$10 A / R-25864-222$
GAS

NOX

SPAN RANGE OPERATOR
2500PPM JOSE PEREZ

$========$
SPAN DRIFT

\begin{tabular}{|c|c|c|c|c|c|c|}
\hline & 1 & 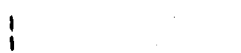 & CALIBRATION & MONITOR & ERENCE & CENT OF \\
\hline DAY & DATE & TIME & VALUE PPM & IVALUE PPM & IN PPM & ISPAN VALUE \\
\hline TART & |12-Ju1-91 & 108:00 AM & 1500 & 1500 & 0 & $0.00 \%$ \\
\hline 1 & $13-J u$ & $06: 15 \mathrm{AM}$ & 1500 & 14 & -3 & $-0.12 \%$ \\
\hline 2 & |14-Jul & $06: 10 \mathrm{AM}$ & 1500 & 1489 & -11 & $-0.44 \%$ \\
\hline 3 & 15-Jul & $08: 25$ AM & 1500 & 1488 & -12 & $-0.48 \%$ \\
\hline 4 & $16-J u 1-$ & $106: 25$ AM & 1500 & 1505 & 5 & $0.20 \%$ \\
\hline 5 & |17-Jul-91 & $106: 10 \mathrm{AM}$ & 1500 & 1507 & 7 & $0.28 \%$ \\
\hline 6 & 18-Jul- & 05:55 AM & 1500 & 1507 & 7 & $0.28 \%$ \\
\hline 7 & $19-J u 1-91$ & $05: 55$ AM & 1500 & 1505 & 5 & $0.20 \%$ \\
\hline
\end{tabular}

ZERO DRIFT

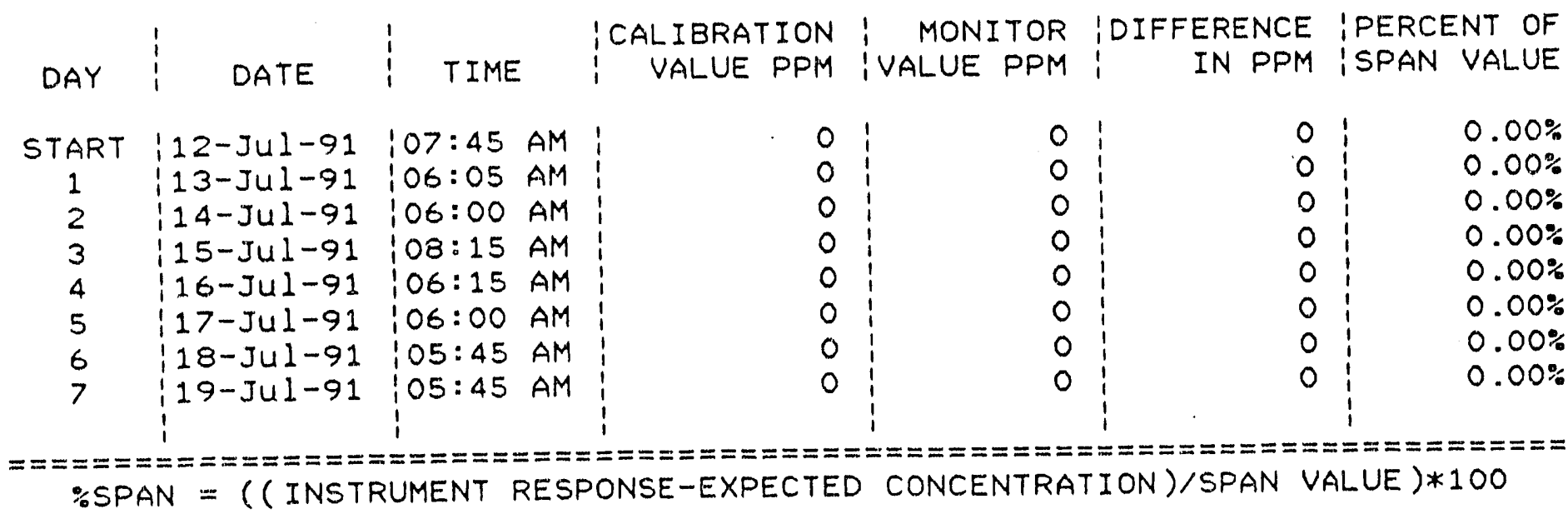


CALIBRATION DRIFT DETERMINATION

DOE/SOUTHERN COMPANY SERVICES, INC.

INNOVATIVE CLEAN COAL TECHNOLOGY PROJECT

GEORGIA POWER COMPANY - PLANT HAMMOND UNIT FOUR

SYSTEM

MANUFACTURER

MODEL.

SERIAL NUMBER
KVB-O2

AMETEK

WDGI I I

C058405(B)-1
GAS

SPAN RANGE OPERATOR
$\mathrm{C2}$

25PCT

JOSE PEREZ

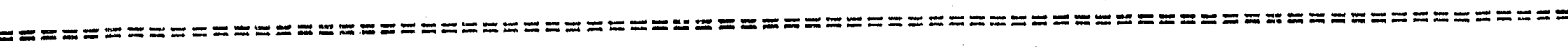
SPAN DRIFT

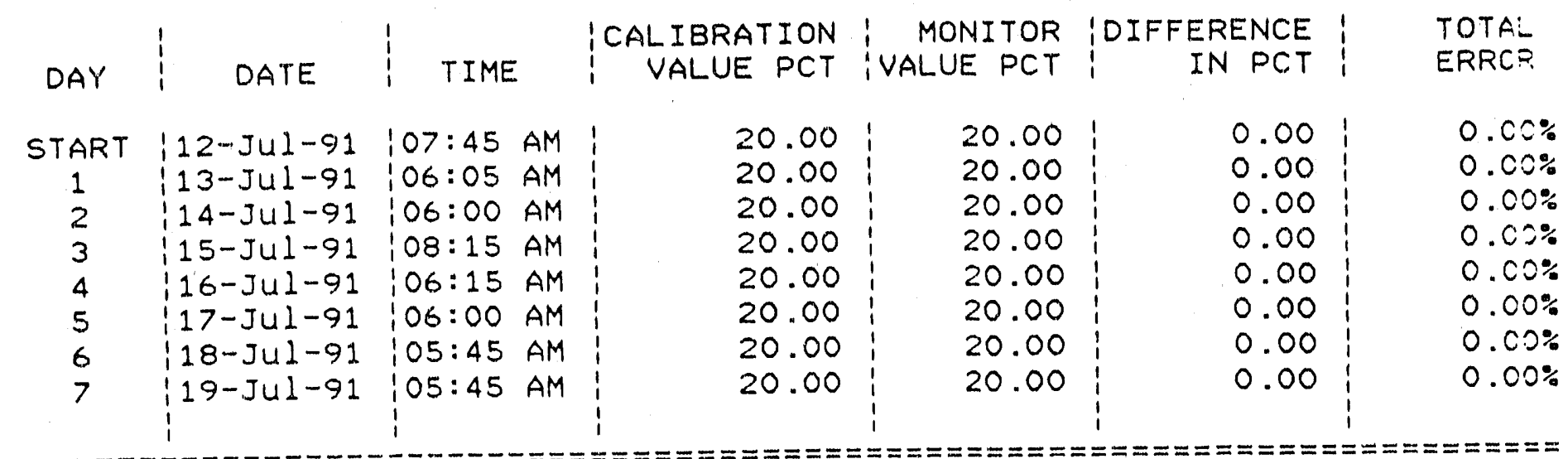

$=========$
ZERO DRIFT

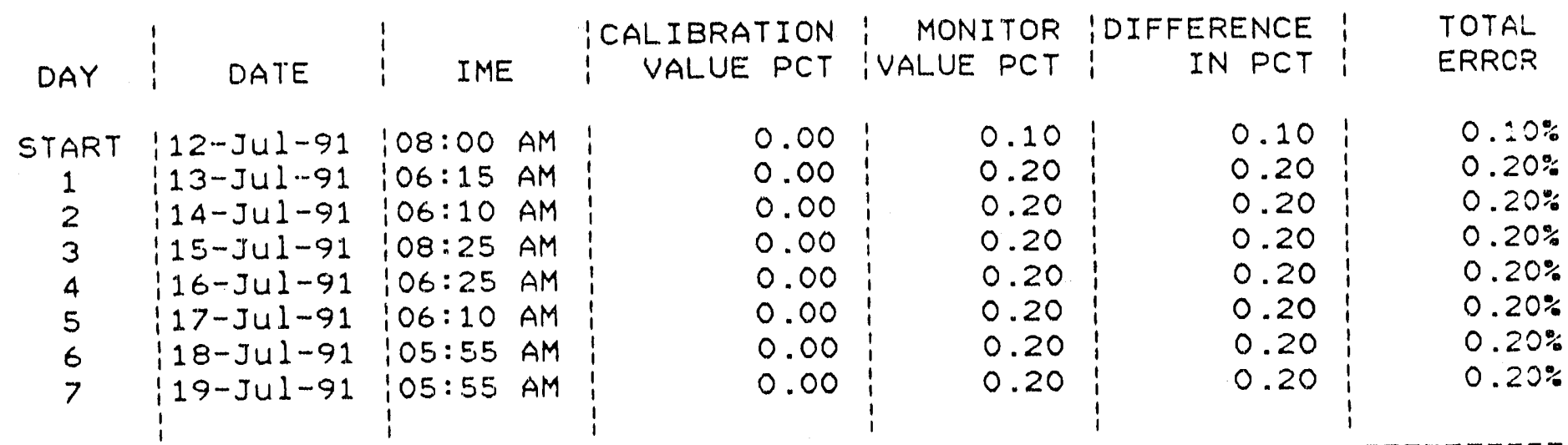

MAXIMUM ALLOWANCE ERROR = PLUS OR MINUS $0.5 \% 02$ BY VOLUME 
GEM RELATIVE ACCURACY DATA 
KVB SYSTEY

Rolatlve Accuracy Doteralnatloa

CEN-DRY RH-DRY

SPECTRUH SYSTENS IHC.

3110 Y. 9 HILE ROAD

PENSACQLA, FLORIOA 32526-7808

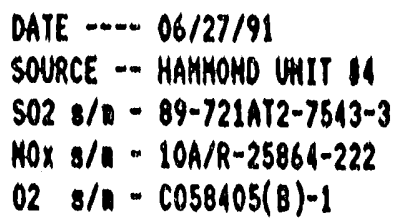

Fd $=9780$

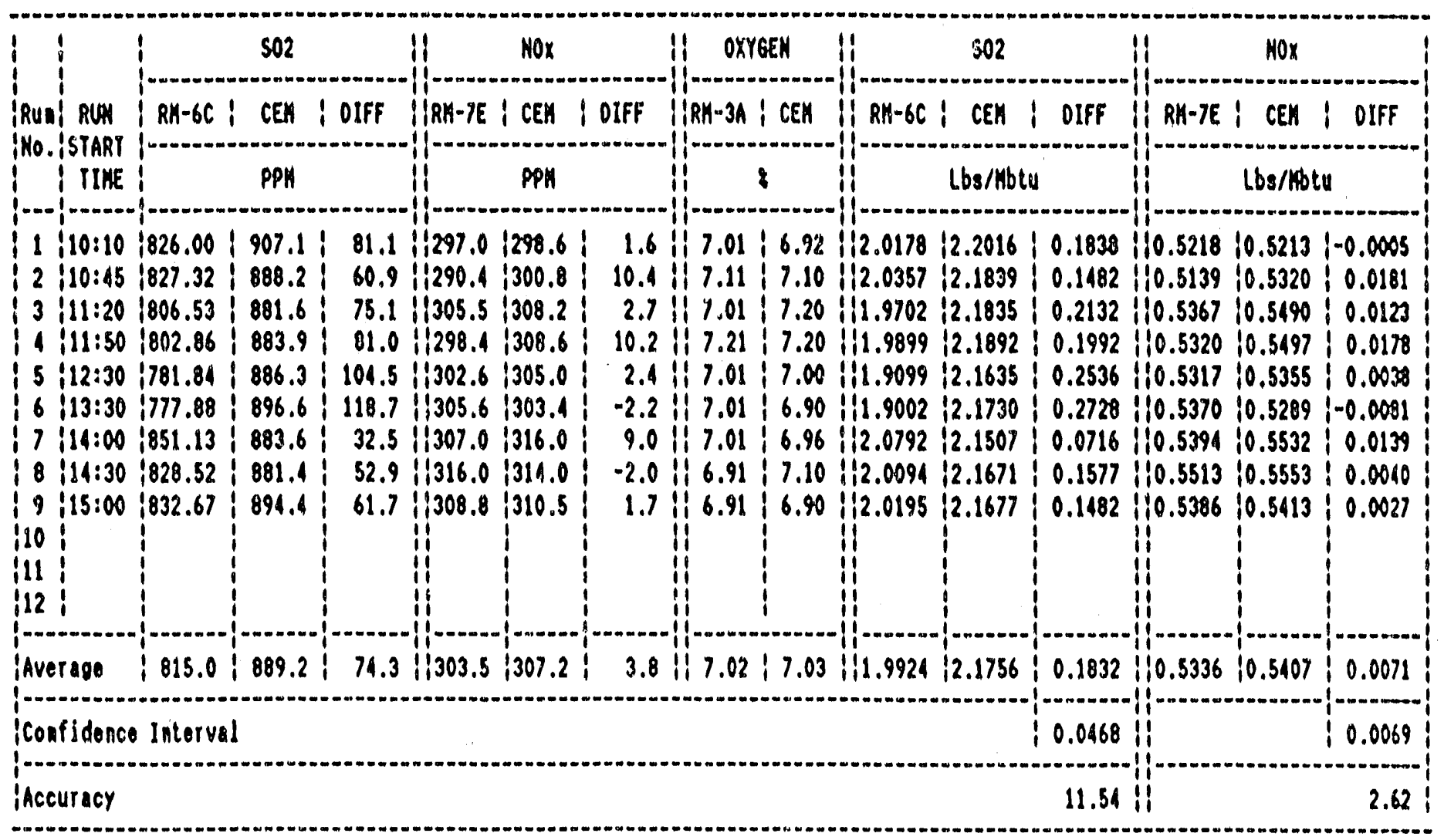


V. APPENDIX 


\section{NOTICE OE EIELD CERTIFICATION - KYB CEMS.}

Certification is hereby given that the KVB stack gas monitoring system ( $/ \mathrm{N} 50525)$ described below has been installed, tested, and satisfactorily evaluated in accordance with EPA requirements, CFR, Title 40, Part 60 , Appendix $B$, Specification 2 as promulgated in the May 25, 1983 Eederal Register, Vol. 48, No. 102, Part IV. Relative accuracy and calibration drift have been demonstrated over the required seven (7) day period in accordance with Paragraph 6 and have been shown to meet specification. Copies of the attached certified test data can be submitted to the appropriate regulator agency in compliance with source performance monitoring requirements. Additional copies are available by request from Spectrum Systems, Inc.

Customer: Georgia Power Company, Plant Hammond, Unit \#4

Diluent O2 Serial Number: CO58405(B)-1

721-AT SO2 Stack Gas Monitor s/n: 89-721AT2-7543-3

10 A/R NOx Stack Gas Monitor s/n: 10 A/R-25864-222

Gas: $\mathrm{SO} 2$

Measurement Range ppm: $\quad 0-2500$

Data Logger - Model: Kaye 4M Plus

Instrument Output (MA/DC): $\quad 4-20$
Gas: NOx

Measurement Range ppm: $\quad 0.2500$

Data Logger - Model: Kaye 4M Plus

Instrument Output (MA/DC): $4-20$

Certification Test Results:

$\mathrm{SO} 2$.

$\mathrm{NOx}$

$\mathrm{O} 2$

EPA Specs.

Zero Drift (24 hr.):

$0.92 \% \quad 0.60 \%$

less than or equal to

$2.5 \%$ per day

-..- $\quad 0.20 \% \quad$ less than or equal to

$0.5 \%$ O2 per day

Calibration Drift $(24 \mathrm{hr}) \quad-.0.88 \% \quad-0.48 \% \quad \ldots \quad$ less than or equal to

$2.5 \%$ per day

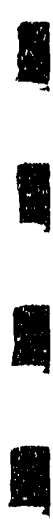

$\ldots$

$0.00 \%$ less than or equal to

$0.5 \% \mathrm{O} 2$ per day

Relative Accuracy $\quad 11.54 \% \quad 2.62 \% \quad \ldots \quad$ less than or equal to $20 \%$

Test Performed by: José Perez

Date: $06 / 27 / 91$

Test Reviewed by: Nick Dixon

Date: 7/25/91 


\section{REPORT CERTIFICATION}

The sampling and analysis for this report was carried out under my direction and supervision.

Date: $\quad 06 / 27 / 91$

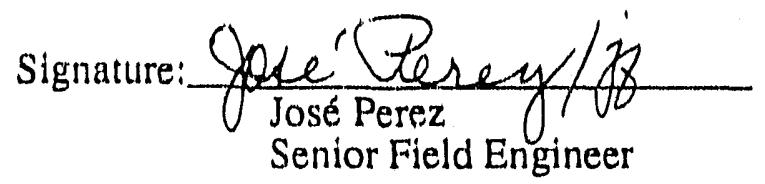

I have reviewed the testing details and results in this report and hereby certify that the test report is authentic and accurate to the best of my knowledge.

Date: $\quad 07 / 25 / 91$

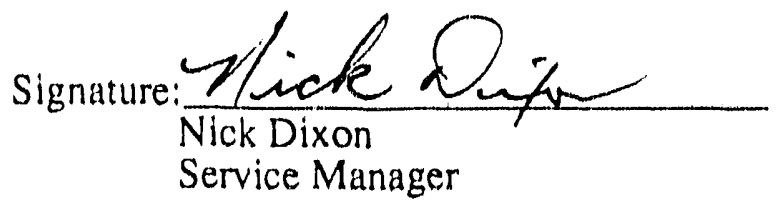



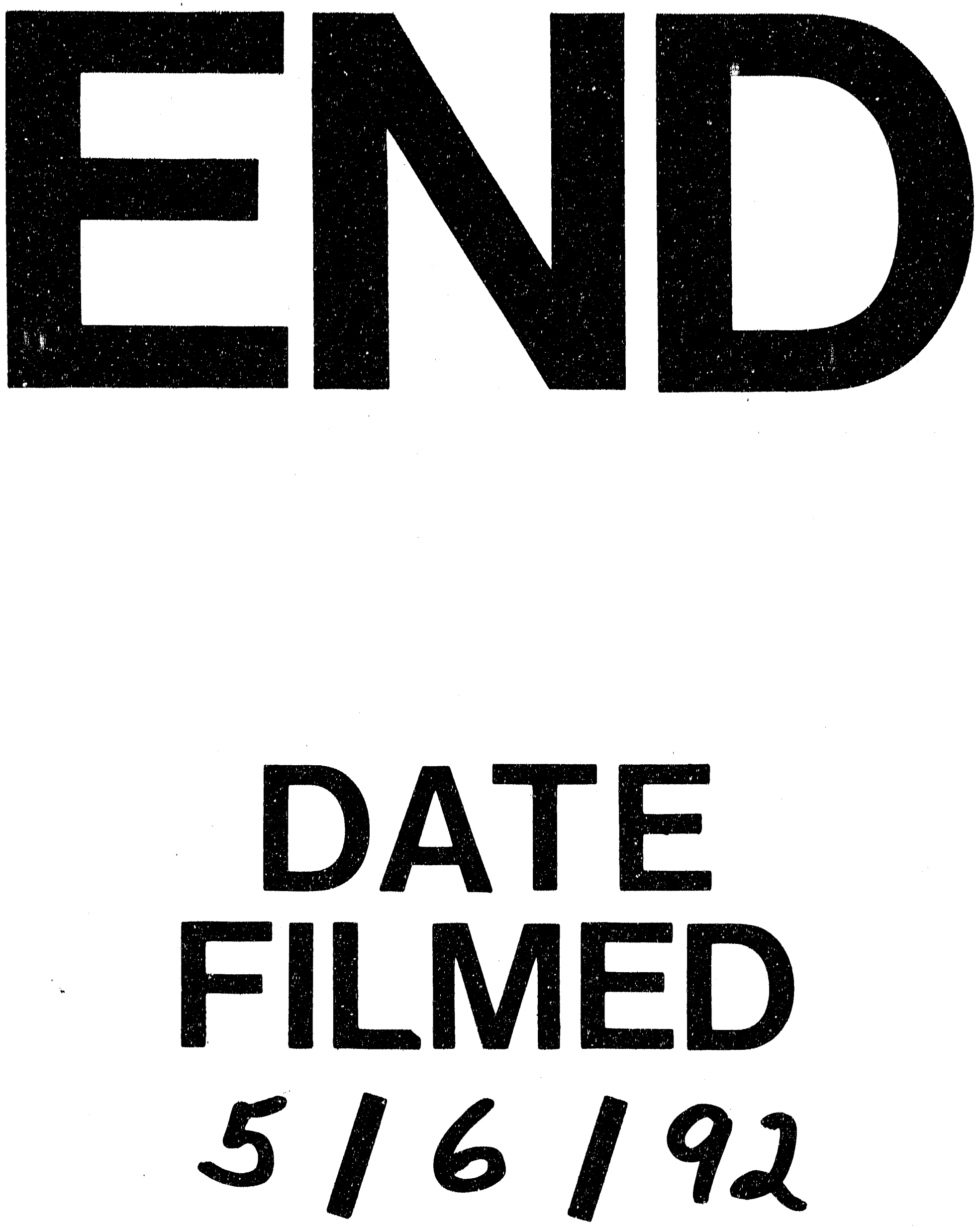
